Res judicata and null and void judgment in the Italian and German doctrine of Sixteenth - and Seventeenth - century criminal law. Certain interpretative profiles

\title{
Antonella Bettoni
}

\section{OpenEdition}

\section{Journals}

Electronic version

URL: https://journals.openedition.org/chs/68

DOI: $10.4000 /$ chs. 68

ISSN: 1663-4837

\section{Publisher}

Librairie Droz

\section{Printed version}

Date of publication: 1 April 2008

Number of pages: 65-96

ISBN: 978-2-600-01237-9

ISSN: $1422-0857$

\section{Electronic reference}

Antonella Bettoni, "Res judicata and null and void judgment in the Italian and German doctrine of Sixteenth - and Seventeenth - century criminal law. Certain interpretative profiles", Crime, Histoire \& Sociétés / Crime, History \& Societies [Online], Vol. 12, $n^{\circ} 1$ | 2008, Online since 01 April 2011, connection on 22 March 2022. URL: http://journals.openedition.org/chs/68 ; DOI: https://doi.org/10.4000/chs.68

This text was automatically generated on 22 March 2022.

(C) Droz 


\title{
Res judicata and null and void judgment in the Italian and German doctrine of Sixteenth - and Seventeenth - century criminal law. Certain interpretative profiles
}

\author{
Antonella Bettoni
}

«Justice is the first virtue of social institutions, as truth is of systems of thought»

(J. Rawls $)^{2}$

\section{Introduction}

1 It is 1561, the Republic of Genoa judicially concludes a dramatic series of events that happened about fourteen years before. Filippo Casoni ${ }^{3}$, a century later, describes the year 1547 as grieved by atrocissimi accidenti: citizens' plots, princes' conspiracies, subjects' disloyalties, changes in the law, councils' conflicts and private nuisances and rivalries ruled; fear and danger reigned and liberties were at stake. One event especially marks that year: the plot of the Fieschi ${ }^{4}$

2 The malcontent has long roots and has one of its seeds in the institutional reform of 1528, with which Andrea Doria and Sinibaldo Fieschi sanction a compromise between the old and the new aristocracy in Genoa ${ }^{5}$. The Doria family, asientists ${ }^{6}$ of galleys, represents the mercantile and cosmopolitan vocation of the town. The Fieschi family, owners of one of the biggest Italian fiefs, represents the landed aristocracy.

3 The death of Sinibaldo Fieschi in 1532 jeopardises the agreement and determines the progressive marginalisation of the feudatories from the town politics and the strengthening of alliances between bankers and shipowners. All the people who are dissatisfied by this course of political events gather around Gian Luigi Fieschi who is 
able to attract, to his cause, not only the anti-government Genoese faction, but also certain foreign powers, France and the Papal States, which aspire to 'rescue' Genoa from Spanish control and subdue it to their own. In January 1547, such a composite group, led by Gian Luigi Fieschi, tries to overthrow the government of Andrea Doria. The uprising is unsuccessful and the repression is unmerciful: the body of Gian Luigi Fieschi, who fell into the sea while crossing a gangplank between two galleys and drowned, is fished out of the water and put on public view in the dockyard, the Fieschi town residence and their castle in Montoggio are razed to the ground. In 1548 the last of the Fieschi family, Scipione, together with his brother-in-law, Giulio Cybo, again tries to overthrow the government of Andrea Doria. The revolt is stifled from the very outset, Cybo is captured and killed, while Scipione manages to flee over the border.

In Genoa an inquisitorial proceeding is started in Scipione's absence with the charge of lese-majesty ${ }^{7}$ against the emperor, the Genoese government being faithful to the Spanish crown. The trial, started in March 1550, is entrusted to a judge delegated by the emperor Charles V, a certain Gomez Suarez Figueroa who is the Spanish ambassador to Genoa. The intervention of the emperor Charles $\mathrm{V}$ in the judicial proceeding - intervention required and strongly demanded by Andrea Doriacontextualises the conflict in a different environment. From struggle between two rival factions for the domination of the Genoese Republic, it becomes crime of lese-majesty against the emperor to whom Genoa is faithful. The trial ends in 1552 with a verdict of guilty. Scipione cannot go back to his homeland otherwise the death sentence will be executed, he is deprived of all his rights, fiefs and privileges. The dismemberment of the vast feudal possessions of the Fieschi family is completed and Scipione takes residence at the French court.

5 The peace treaty of Cateau-Cambrésis, signed in 1559 between France and Spain, mentions Scipione Fieschi and entitles him to claim his feudal estates against those who own them at the time ${ }^{8}$. Ferdinand I, who succeeds Charles V in 1558, pardons Scipione and re-invests him with his former fiefs. In 1562, Scipione starts a legal action against the Genoese Republic at the imperial court of Prague, declares to have been badly judged, proclaims his innocence for the crime of lese-majesty and raises thirty-three exceptions of voidness against the judgment which has already passed in rem judicatam, with the purpose of having the sentence declared null and void.

6 The Genoese Republic submits the petition and the exceptions of voidness to the most eminent jurists of the time for examination, among them there are Ioannis Nervius, Ioannis Cephalus, Tiberius Decianus, Jacobus Menochius and the College of jurisconsults of Padua9. The jurists' responsa, given between 1571 and 1572, substantially agree in dismantling the defensive castle built by Scipione Fieschi's lawyers and invite the judges to reject the petition and the exceptions of voidness raised by Scipione.

7 The responsa, given by the most authoritative jurisconsults: Decianus ${ }^{10}$ and Menochius ${ }^{11}$, are mainly made up of two parts: one which pertains to the fact and is directed towards ascertaining the existence, in the case, of the crime of lese-majesty; the other regarding the judicial proceeding, and, therefore, aimed at verifying the existence in it of procedural errors which may produce a null-and-void sentence. The latter is indeed the part taken into consideration in this research.

8 Res judicata and voidness are the two threads with which Decianus and Menochius's consilia are woven. The pattern that emerges from the weaving tells us the story of the 
political and social dynamics which underlie the legal discipline of res judicata and null and void judgment in the Sixteenth and Seventeenth centuries.

Once the phase of the open conflict has ended, it is by means of the judicial proceeding that things are settled. Scipione's extreme attempt at having the judgment declared null and void can be read as a sort of opinion poll. Scipione puts out feelers in order to evaluate his possibilities of going back to his homeland.

The choice of the judges, in 1574, to keep the res judicata firm is not only a judicial choice, it is above all a political choice and is a clear answer for Scipione. A complex balance between judicial and political reasons characterises every trial. The rules that govern the procedure have a certain margin for interpretation and often produce results in tune with the orientation of the political establishment.

11 In the Sixteenth and Seventeenth centuries, the process of publicization of criminal justice strengthens the authority of the res judicata ${ }^{12}$ which becomes a ruling instrument and a tool with which parties' capacity to settle a dispute is taken away.

12 Starting from the definition of res judicata as the irrevocable end of a correctly constructed judicial proceeding we will investigate that which, in the Sixteenth and Seventeenth centuries, gives substance to it. We will see what the differences are between final judgment and res judicata and the relationship between appeal and res judicata. Then we will examine the elements which constitute the authority of the res judicata and the iuris et de iure presumption which gives it foundation. Finally, we will investigate the errors that can make the judgment null and void and, therefore, produce the rescission of the res judicata.

13 This well ordered research path presents a problematical aspect, connected with the inquisitorial trial and the res judicata, represented by the truth. Truth and res judicata could indeed diverge. As we will see, such possible dichotomy creates a number of challenging questions and produces, a lively doctrinal debate concerning the conscience of the judge and the behaviour he has to retain in case the evidence he has gathered during the judicial proceeding clashes with the truth of the facts which he knows through personal knowledge.

14 In criminal justice, since life, freedom, goods and fama of the accused are at stake, the search for the truth assumes a particular political value and is connected to questions of political opportunity, such as the protection of the established social order. Therefore the procedural choices not only have an epistemological value but also an historical and political one ${ }^{13}$.

\section{Res judicata and final judgment}

Settlements, reconciliation, peace-making and the res judicata all have one thing in common: all determine pacification of the parties in conflict, and all mend the social fracture produced by a crime. In the Thirteenth century, once a crime is committed, the victim can seek satisfaction by revenge, but this practice is strongly contrasted by the public authority because it produces disorder and law breaking, so the injured party is instead encouraged to begin a peace-making procedure with the help of mediators, and/or to start an accusatory criminal trial against the offender. The party's choice of the most convenient path to follow is determined by social, economic and political reasons. In the coming centuries this great power of option is destined to be 
gradually taken away. The story of such subtraction concerns the history of European criminal justice for a period of about three hundred years and is linked to the steady passing from a form of so-called "negotiated" criminal justice (based on settlements between offender and victim), to a form of criminal justice properly named "hegemonic", that is, coming ex officio ${ }^{14}$ from a public judicial apparatus ${ }^{15}$.

"Hegemony" is a well known category in social history and was first highlighted by Gramsci in his Quaderni dal carcere. It indicates a model of power and «encapsulates the notion that the power of a ruling class [is] exercised less by coercion than by its intellectual and moral capacity to win the consent of the mass of the population. ... Especially important for Gramsci [is] the transition in early modern Europe from an aristocratic society, where the political class [is] kept aloof by an effective caste system, to a capitalist society, in which a bourgeois state actively [seeks] to mobilise society as a whole in support of its aims and projects» ${ }^{16}$. Sbriccoli, a fine expert in Gramsci's work, uses the category of hegemony in order to describe the phenomenon of publicization of criminal justice in the early modern period and frames it within the legal and judicial system.

17 At the beginning of the Fourteenth century a strong character of publicization is impressed onto the criminal justice system. Town governments become aware that criminal justice is a decisive ruling instrument and therefore it cannot be left to the sole initiative of the victims. Judges prosecute crimes and convict the offender, even if the victim, having been negotially satisfied, has reconciled with him and has no more interest in the judicial proceeding ${ }^{17}$. In the Sixteenth century, between the offence and the satisfaction of the injured parties, between the crime and the re-establishment of public order, the res judicata interposes. This is regulated by principles included in the Corpus Iuris Civilis ${ }^{18}$ and in the compilations of canon law ${ }^{19}$, but especially by doctrinaire works which flowered all around them. The value given to the res judicata is a possible indicator of the degree reached by the process of criminal justice publicization.

The analysis of the elements that in the Sixteenth and Seventeenth centuries constitute such value may, perhaps, allow us to provide a contribution for the theory that postulates the affirmation of hegemonic criminal justice.

Before entering into the heart of the matter, it is necessary to provide certain definitions in order to establish sound points of reference.

As for the definition of res judicata, not only have criminal law jurists been used but also jurists that are concerned with civil law, in that, throughout the Sixteenth and part of the Seventeenth century, criminal law borrows civil law categories to construct its own institutions ${ }^{20}$.

21 When jurists define res judicata, they distinguish it from the final judgment ${ }^{21}$. By final judgment, they mean a decision of the judge that defines and concludes the main subject of the case and that, therefore, necessarily contains words of acquittal or conviction $^{22}$. Yet, the res judicata presents something more, an added value, if compared with the final judgment pronounced by the judge: the judgment passes in rem judicatam ${ }^{23}$ following ten days, during which time, making an appeal is permitted ${ }^{24}$. The ten days given to the parties to appeal, are provided for by a principle of ius commune and represent a necessary break between trial and judgment, on the one hand, and the res judicata, on the other. A pause that allows the parties to evaluate the work done by the judge and its results, as well as to identify possible reasons for appealing. The 
appeal, as far as ius commune is concerned, is not permitted in only two cases: when the accused has confessed of his own free will and when the crime is notorious ${ }^{25}$.

\section{Appeal and res judicata} There are areas where appeal of criminal decisions is allowed. Brunnemann ${ }^{32}$ states that in the Brandenburg courts, appeal is permitted also in inquisitorial trials and Berlich $^{33}$ sustains the same for the courts of Saxony. However the rules concerning the appeal within the German regional principalities represent a more complicated problem than what could be envisaged at the outset, and if we examine, in greater detail, Saxony for example, we find out that the landscape is much more varied. Theodoricus ${ }^{34}$, while talking of the courts of Saxony, explains that the dichotomy between what is established in imperial constitutions and what is locally practised is due to the fact that the laws of the empire, above all, apply to the Reichskammergericht, and they cannot, and must not, be extended to the lower courts. He then goes on to specify that such a general, imperial norm, which does not allow for appeal in criminal cases, is linked to the inquisitorial trial in which the judge proceeds ex officio against the criminal, and which aims, mainly, at obtaining a confession from the defendant. He then concludes that, in those cases where an 'ordinary' - meaning 'accusatory' - trial is instead brought against a criminal, such imperial norm must not be observed, because the denial of appeal outside the Reichskammergericht is considered an extremely severe rule.

Carpzov, an eminent Saxon criminalist, seems to have a similar position: he affirms the right to appeal in criminal accusatory trials and denies it in criminal inquisitory trials. However, unlike Theodoricus, he is aware of the growing diffusion of the criminal inquisitory model also in the lower courts ${ }^{35}$ and he is really concerned about the professional and personal qualities of the judges that sit in Saxon criminal courts. He describes them as cruel and easily seduced by money, to which features he adds the inexcusable lack of knowledge of criminal law and constitutions for the judges of the lower courts ${ }^{36}$. Therefore, Carpzov considers the transmission of the judicial acts to the colleges of jurisconsults of the great German faculties of law or to the higher courts provided for by article $219 \mathrm{CCC}$, a necessary part of the inquisitorial trial ${ }^{37}$. According to the jurist, even when the judge is honest and expert the transmission of acts is indispensable, because it cannot be accepted that criminal cases which deal with men's goods, fama and life undergo only one degree of adjudication ${ }^{38}$. For the same reasons 
expressed above, Carpzov holds that in the criminal inquisitory trial the defence of the inquisitus has to be admitted, if indeed he cannot appeal against a conviction, he should be able to prove his innocence and the execution of the sentence has to be suspended ${ }^{39}$.

The rule that forbids appeal is widespread in the Courts of the Italian States, but it is often criticised and in certain areas is not followed or is substituted by other remedies. The appeal, according to Clarus ${ }^{40}$, concerns the right of defence that is part of the rights that naturally belong to each man and that, therefore, cannot be taken away from him by laws and statutes. However, the situation with which the jurist does his sums is quite different, and as he himself admits, in the Duchy of Milan, the laws in force at the time do not allow for making an appeal against criminal decisions. In the Princedom of Piedmont and Savoy, Menochius affirms that, even though making an appeal in criminal cases is not permitted, however re-hearing of the trial is allowed ${ }^{41}$. Farinacius refers that in his everyday experience in Rome Papal courts, appeal is forbidden in criminal cases only when they deal with certain atrocious crimes, and solely if those crimes are fully proved, or if the defendant has been caught in flagrant delict or has given a full confession. In the other cases the appeal must be provided for, because the atrocity of the crime is not a sufficient reason for its removal ${ }^{42}$. Baiardus in his Additiones to Clarus' Pratica criminalis, states that, as far as he could observe, it is forbidden to make an appeal against a sentence for murder in the Kingdom of Naples, however in practice the rule is not followed, instead ius commune is applied which permits the right of appeal ${ }^{43}$.

The appearance of rules that forbid appeal in criminal cases, has definitely something to do with the progressive expansion of the inquisitorial model in the judicial courts throughout Germany and Italy and meets strong criticism and resistance to its application. The elimination of the right of appeal indeed satisfies criminal policies which intend to put the problem of the causes' length right ${ }^{44}$, but at the same time it sacrifies one of the guarantees that are provided for the convicted ${ }^{45}$.

Moreover, the morphology of the res judicata is modified by the lack of providing for appeal in criminal decisions. It is no longer necessary that the time for appeal has clapsed as far as the passing in rem judicatam of the judgment is concerned. Final judgment and res judicata almost end up coinciding. The execution of the criminal sentence, usually delayed at the time of passing in rem judicatam, may be started immediately, following its rendition. Certain authors of criminal practices, aware of the dangers that may derive from that, provide for a series of cases which, should they come about, lead to respite of the execution ${ }^{46}$. Among these, for example, there is that of the judgment which sentences to a more serious punishment than the one usually imposed, in such a case the execution may be respited for 30 days $^{47}$.

\section{The authority of the res judicata}

In the Sixteenth and Seventeenth centuries, the res judicata is conceived as a rule and therefore presents normative and executive characters.

The res judicata, as can be read in the Tractati and in the Practicae of ius commune jurists, is a particular rule in that it concerns only the parties and has legal force between them ${ }^{48}$. The parties, therefore, have to conform to it and will bear all effects deriving 
from it. The res judicata can produce effects towards third parties only in certain, well determined cases $^{49}$.

The res judicata can, at times, assume the status of general rule, when the authority of the court which renders the judgment engraves this character into it. The judgments rendered by the prince, the Pope or the emperor ${ }^{50}$, but also by certain supreme courts ${ }^{51}$ possess this character.

The normative nature of the res judicata reflects some indirect consequences on the activity of those who make the law. The power to produce rules of the prince and of town councils, even though it is not limited by what is established by the res judicata, nevertheless cannot produce effects upon it: that is following and contrary decrees or statutes cannot be opposed to $\mathrm{it}^{52}$. The power of judging of magistrates is limited by the res judicata: in a positive way, in as much as judges often pronounce in accordance with a previous res judicata in those cases with a certain analogy to it; and, in a negative way, in as much as magistrates cannot judge the same case between the same two parties. As far as the former limitation is concerned, we can point out that in the early modern period in Italy and Germany there is no principle similar to the English rule which imposes respect for the precedent. Nevertheless, certain law courts develop their own stylus iudicandi, the usus fori are commonly followed and collections of the decisiones of the great law courts spread ${ }^{53}$. As far as the second limitation is concerned, the exceptio rei judicatae is linked to it and is established for the protection of the ne bis in idem principle. Jurists agree in maintaining that the magistrate cannot judge a particular crime where the following conditions come to light: the existence of a judgment passed in rem judicatam which concerns the same fact, the same parties and the same case, for the reason that the same petitum cannot have two rendered judgments which are both valid $^{54}$. The second judgment is necessarily null and void ${ }^{55}$ even in the case where it has been pronounced with the consensus of both parties ${ }^{56}$.

«Validiora tamen sunt prioris sententiae presidia: nam et auctoritate rerum judicatarum fortissime defenditur» (However the garrisons of the prior judgment are most effective: indeed they are really strongly defended also by the authority of the res judicata), affirms Matthaeus ${ }^{57}$ in the first half of the Seventeenth century, confirming that the authority of the res judicata is a garrison for the protection of the judicial decision and therefore of the principle of ne bis in idem. Jurists, nevertheless, elaborate an ingenious sophism which consents them to get round the ne bis in idem principle. Farinacius, agreeing with a communis opinio, affirms that it is possible to start a new judicial proceeding against the same person for the same fact if a qualitas delicti is such that it produces a modification of the substantia delicti: for example, if the killing of a person is first qualified as murder and then as parricide ${ }^{58}$.

The normative character of the res judicata produces effects upon the parties' authority to settle a dispute.

Sixteenth- and Seventeenth-century jurists affirm that a previous settlement between the parties on the same matter cannot be opposed to the res judicata ${ }^{59}$. Clarus, for example, affirms that a custom which is widespread throughout all the Italian princedoms establishes that the judge can start an inquisitory trial to prosecute whatever kind of crime, and it is of no importance if the parties have promoted an accusatory trial or have settled the dispute already: the parties' pacification does not and cannot stop the judge's inquisitorial action ${ }^{60}$. Carpzov declares that the settlement between the offender and the victim does not prejudice the public revenge. The party 
can indeed give up the prosecution of the crime to his detriment, but not to the respublica's prejudice ${ }^{61}$. Brunnemann ${ }^{62}$ agrees with Carpzov, and adds that a settlement with the victim is one of the reasons for beginning an inquisitorial trial ${ }^{63}$. The parties are also not permitted to settle a matter that has already been judged. Indeed Wesenbeck affirms that since the right of the parties is made certain by the res judicata, the settlement is no longer needed, in that there are no longer dubious and uncertain matters which have to be settled ${ }^{64}$. Brunnemann states that it is not permitted - not even to the judge - to end the proceeding with a settlement. Once the inquisitory trial is started judges can only inquire, convict or acquit, because to this purpose have they been appointed ${ }^{65}$.

The normative character of the res judicata is necessarily complemented by its enforceability. Once the judgment passes in rem judicatam, perfection, irrevocability and enforceability are added to it.

The irrevocability of the judgment is substantiated by not being able to be further modified $^{66}$ and it opens the doors to its enforcement ${ }^{67}$.

«Et stante res iudicata non cognoscitur amplius de iustitia, vel iniustitia, sed de executione» (Once the judgment passes in rem judicatam, justice or unjustice does not matter any more, only its execution matters) ${ }^{68}$. The final judgment of the magistrate, indeed, defines the case, but cannot be immediately executed. The res judicata plays an important role in the architecture of criminal justice that is maintained in a cohered state and may release all of its power thanks to the executive power which derives from it.

The jurists are extraordinarily eloquent when describing the effects produced on real life by the authority of the res judicata. A very impressive description states that the res judicata makes white become black, and black, white; it makes the undue, due; the nonheir, heir; it changes truth into falsehood and falsehood into truth. It makes abuse, right. It is source of law and, therefore, it can make the foreigner a citizen and the Guelph a Ghibelline, whether it damages or favours the party. Showing great clearness, however, jurists admit that these changes do not concern the essence of the matter, rather, they are important as far as the effects caused by the res judicata are concerned ${ }^{69}$. The res judicata is indeed unable to change the substance of goods and relationships, it can, however, reconstruct and feign a different one and make effects leap to the fore from such a reconstruction.

\section{Res iudicata pro veritate accipitur}

40 The whole construction of the res judicata: its legal force among the parties, its enforceability and the effects which it can produce, stands on a iuris et de iure presumption $^{70}$. A character of truthfulness is attributed to the iuris et de iure presumption against which rebuttal evidence is not admitted ${ }^{71}$.

41 Jurists $^{72}$ say that if the judgment is pronounced rite et recte, after its passing in rem judicatam it is held firm by a iuris et de iure presumption. The truthfulness character of that iuris et de iure presumption which is at the core of the res judicata is made explicit by the jurists. They eliminate the intermediate term (iudicatum - praesumptio - veritas) and establish a straight and direct equation between truthfulness and res judicata ${ }^{73}$. Such equation finds its basis in title 17, De regulis iuris, of book 50 in the Digest ${ }^{74}$. In it, 
lex 208 relates «res iudicata pro veritate accipitur» (res judicata is assumed as truth). Res judicata and truth, justice and truthfulness: both equations are part of an absolute knowledge for which the sovereign power vouches ${ }^{75}$. This monolithic union between ethical and juridical values is still sound in the Sixteenth century and Iacobus Menochius $^{76}$ affirms that the res judicata is not the truth itself, but is held to be the truth.

The presumption, which links the res judicata to the truth, creates a virtuous circle in which every single judgment is a reassertion of the legitimacy, validity and effectiveness of the whole juridical system. Every single judgment which comes to life, which passes in rem judicatam, and which produces its effects, bears witness that the juridical order, which generated it, is lawful, valid and effective. Every res judicata which is presumed true and which reaches the real truth of facts, on the one hand, confirms the good quality of the procedural law followed by the judge and its good application: the procedural law becomes the instrument which makes the judge able to reach the truth. On the other hand, it confirms the good quality of the substantial law applied by the judge and its capacity to produce justice.

The inextricable bond between justice and truth represents the challenging knot in every inquisitorial proceeding.

«Veritas est mater iustitiae» (Truth is the mother of justice) says Baldus ${ }^{77}$ at the end of the Fourteenth century, and these words become a communis opinio still shared and followed in the Sixteenth and Seventeenth centuries, as its presence in the Summaries of law doctrine ${ }^{78}$ bears testimony. Justice is generated by truth, therefore there is a strong mother-child relationship between them. Justice can only derive from truth and only in truth is there justice.

In every trial each party has its own truth to assess in order to reach its own particular justice. This statement challenges the inquisitorial system which is based on the axiom that there is only one truth. Within this system, judges - who represent the highest social institution: the res publica, and dispense public justice - assume the attainment of the truth as final goal of their judging activity. Good judges, being super partes, can and should reach the truth. "In iudicando judex debet semper habere veritatem prae oculis» (When judging the judge must always have the truth in front of his eyes), «Sine veritate bona non potest iustitia ministrari» (Without truth good justice cannot be provided for), «Iudex ad aliud positus non est, nisi ut veritate tueatur» (The judge is established only in order to defend truth), «Iudex debet omnibus modis laborare, ut veritatem quaerat et inveniat» (The judge must work in every way, in order to look for and find the truth) ${ }^{79}$ are only some of the communes opiniones related to judges and their duty of achieving truth.

The first and most evident occurrence, deriving from this way of judging, is the possible splitting of the truth itself into two entities that will endlessly try to unify again: the truth spoken by the judge in the final judgment and maintained firm by the res judicata, and the truth of the facts, of what really happened. Indeed to tighten up the inquisitorial judging system, the res judicata - as final result of this system - must be given a value of truth. "Etiam veritas inducta a lege, prout est res iudicata quae vere et cum effectu pro veritate habetur, attendenda est et praevalet» (Also the truth induced by law, as it is the res judicata, which truly and effectively is considered as truth, must be obeyed and prevails $)^{80}$. There is, therefore, a truth induced / produced by law, in that it is the law which establishes that the res judicata has to be maintained as truth. 
This statement necessarily implies that of the same fact there can be two truths: the truth reconstructed during the trial and deriving from the res judicata and the truth which we could call the truth of the facts or historical truth. Between these two truths there can be a dichotomy which is well known by the jurists, but is denied by the propaganda of the inquisitorial system. The inquisition tends to reach the truth of the facts ${ }^{81}$. However between the fact and the final decision there is a cognitive emptiness that the judge has to fill by means of various methods of inquiry: the same body of the accused can become an instrument which, if properly played, could lead the judge to the truth. Nevertheless in the process of collecting and evaluating evidence, a mistake, an error, an inaccuracy, a misinterpretation could occur and the inquiring path could forever diverge from the path leading to the truth.

In 1628 using a beautiful image Harpprecht ${ }^{82}$ describes the work of the judge comparing it to that of architects and geometricians. They, using the plumb line, restore harmony, symmetry and proportion between unequal spaces as the judge restores harmony, proportion and equilibrium - where they have been compromised - with an exact judgment. The Latin word exactus, as past participle of the verb exigo, carries within itself the concept of rigorousness in measuring, weighing, pondering, evaluating hints, circumstances, suppositions, presumptions, proof. Moreover the word exactus finds its most appropriate use in the field of mathematics and geometry. Theories, which require the application of a rational method to jurisprudence and which are comprehensively developed few years later, are coming to light. In 1637, two years before Harpprecht's death, in France Descartes publishes his Discours de la méthode in which he affirms that the mathematical and geometrical method has to be generalised and applied to all human disciplines in order to reach the truth. In 1667 in Germany, Leibniz publishes his Nova methodus discendae docendaeque jurisprudentiae: a work of great importance since in it there is an extensive application of the logical mathematical method to law. The German philosopher distinguishes between veritas rationis and veritas facti. The application of the logical mathematical method consents the veritas facti to identify itself with the veritas rationis at infinity.

\section{Null and void judgment}

Essential condition for realising the equation between truthfulness and res judicata is that the judgment has been pronounced rite et recte. The work of the judge acquires a remarkable importance. In order that the presumption comes into existence, it is necessary that he diligently carried out his officium. It becomes, therefore, indispensable to look at the product of the activity of the judge, the judicial decision, because this is what gives substance to the res judicata. Around it, problematical knots are tied which refer to its legitimacy and validity and which can make the res judicata waver.

The authority of the res judicata can cease because of the voidness of judgment.

The judgment bases its legitimacy and validity on: jurisdictio, jus, justitia.

\section{a) Jurisdictio}

51 In the second half of the Sixteenth century Gaill declares that the competent judge is essential part, basis and foundation of the judgment and the res judicata cannot come 
from somebody who lacks the potestas of ius dicere ${ }^{83}$. Around the first half of the Seventeenth century, Brunnemann summarises: «Iurisdictio fundamentum est omnis sententiae» (Jurisdiction is the foundation of every judgment) ${ }^{84}$, using a word iurisdictio - which even if it has assumed a slightly different connotation throughout the centuries, strongly keeps its medieval value and still expresses the power of the judge of ius dicere by means of the judgment ${ }^{35}$. The iurisdictio gives legal strength to the judgment, therefore the judgment has validity in that it is pronounced by a judge who has the potestas of ius dicere. Such potestas comes directly from the prince and in an uninterrupted chain transmits itself to the ordinary magistrates of the higher and lower courts and to the delegate judges. The judgment pronounced by a magistrate who lacks iurisdictio, has therefore no foundation and is affected by voidness ${ }^{86}$.

Among the most common exceptions of voidness pertaining to the lack of jurisdiction, there are those which concern the defect or vices of the delegation of the judge. For example, delegated judges have to present the rescript of delegation ${ }^{87}$ to the court, to which they are appointed, within one year of its granting. Their jurisdiction starts and can be exercised legittimally only after the presentation of the rescript ${ }^{88}$. Regarding the case of Scipione Fieschi, this is the first exception of voidness which he raises against the res judicata that condemns him. Charles V grants Gomez Suarez Figueroa an imperial rescript of delegation the 11th of August 1548, but Figueroa presents it to the Genoese court only the 14th of March 1550. Not having been presented within one year, the rescript is null. Therefore he cannot exercise any jurisdiction over the case, and the res judicata is null and void ${ }^{89}$.

\section{b) Jus}

The judge manages the whole procedural course: from crime information to pronouncement of judgment, and therefore the correct application of procedural practices is entirely in his hands. In order to get a juridically valid judgment it is necessary that the parties have been regularly summoned, the evidence has been correctly secured, the decision corresponds to the criminal charge, is written and read to the parties on a weekday and contains clear words of acquittal or conviction ${ }^{90}$. If procedural norms are not fulfilled, the judgment lacks its substance, therefore, it is deprived of legal efficacy and is null and void. Scipione's lawyers complain of: the absence of defamation and accuser; an invalid citatio(which might be roughly rendered as 'writ of summons'); an invalid court appearance of Doria's lawyer, Hieronymus de Villa; and many other procedural vices.

According to ius commune in order to start an inquisitory trial against somebody, the investigated crime should be attributed to the inquisitus by public rumour, in short he should have mala fama. Since it is lacking, an inquisition could and should not be initiated against Scipione, therefore the judgment is null and void ${ }^{91}$. Moreover the lack of an accuser would not even consent the start of an accusatory trial, so according to Scipione's lawyers no judicial proceeding could be initiated at all against their client ${ }^{92}$. In order to have the judgment declared null and void, they are using rules of the ius commune which are still formally present in the law system and can still be used to support the party's own thesis, but which in practice are overcome by the ex officio judicial proceeding. 
the fact that multiplicity of laws and the manifold variety of communes opiniones represent a great difficulty for the judges, especially for those of the lower courts, who - not always being experts of law - have trouble in finding the right law to apply to cases. Jurists therefore create a doctrinal principle which justifies the judge and lets go unpunished he who judged badly due to error, unskilfulness or negligence ${ }^{102}$. Harpprecht goes so far as to say that in such cases the judgment is not void, but appealable, therefore passes in rem judicatam and is not amendable any more, if the interested party does not present appeal within the ten days established for this purpose $^{103}$.

\section{c) Justitia}

61 The judge must attain the substantial truthfulness of facts, in order to realise justice among the parties.

This idea of justice tightly clinging to truth which can be reached through the rightful work and judgment of the judge, has some of its roots in canonistic science ${ }^{104}$ and feeds the really lively doctrinal debate on the judge's rightness of judging according to conscience or according to judicial evidence ${ }^{105}$. Jurists ask themselves how the judge 
has to behave whenever he knows the truth: for example in the case in which he knows that the accused is innocent while the evidence gathered during the proceeding leads to his conviction. The solution, that some of the jurists single out, is that in such a case the judge has to transfer the case to a higher court or to the prince ${ }^{106}$.

63 Judges, otherwise, must abide by the judicial acts and the evidence gathered during the trial. Jurists are worried by the fact that to let magistrates judge according to conscience could mean letting them act in the most indiscriminate and arbitrary of ways ${ }^{107}$. Jurists are however aware that the aim of human public justice consists in reaching not the absolute truth of the fact, but a truth of the fact which is reasonably known to the judge on the basis of the evidence gathered ${ }^{108}$. Judges are bound to follow public knowledge not only as far as the law is concerned, but also as far as facts are concerned ${ }^{109}$.

This picture acquires a greater complexity if we assume a different viewpoint and take the arbitrium iudicis ${ }^{110}$, a regulated discretionary power of the judge, into consideration. If during the trial, the judge has not reached full proof (two eyewitnesses or confession, according to ius commune) of the fact, but he has gathered sufficient circumstantial evidence against the accused, he can sentence him to a poena extraordinaria, an extraordinary punishment ${ }^{111}$. In this case as well, the truth spoken by the final judgment and kept firm by the res judicata could hypothetically not correspond to the truth of the facts.

This truth reduced, subject to mistakes is the product of public justice. This is the truth that men are made to accept and that is kept firm with the res judicata eliminating the right of appeal.

Indeed, as Scaccia correctly says, the defects of the judicial decisions which are related to justice give the parties the right to appeal, while those which are related to the proceeding give the parties the right to present a quaerela nullitatis ${ }^{112}$. Once the right of appeal is eliminated, the parties have lost a fundamental guarantee of theirs, that which consents the losing party to intervene in order to correct the non-conformity of the judgment with the truth of the fact.

67 For Sixteenth- and Seventeenth-century jurists the elimination of the right of appeal in criminal cases determines the problem of the unjust judgment. Some jurists believe that if the unjustice is manifest, it produces such an error in the judicial decision that it can be considered like those that render the judgment null and void. Others more rigorously declare that the unjustice of the judicial decision does not pertain to the substance of the proceeding and therefore cannot render the judgment null and void ${ }^{113}$. If new evidence, which could not be found during the trial for just cause, arises the unjustly convicted party can claim the restitutio in integrum ${ }^{114}$. In Germany the prohibition of the appeal in criminal cases determines an increase of the petitions for mercy to the Sovereign. The petitions and the mercy that often follows alter the correlation between what is established in the final judgment and what is executed ${ }^{115}$.

It is common place among jurists that judges - in order to judge well - must have two different types of salt in their brain: the salt of science and the salt of conscience. If the first one is lacking, they are insipid and therefore not able to perform their duties, because they are not supported by the knowledge of law. If the second one is missing, they are diabolic, in that judges who do not conform their judgments to truth and justice are ministers of the devil ${ }^{116}$. 


\section{Remedies}

The judge rules the proceedings and therefore the delivery of a correct judgment, on which the formation of a valid res judicata depends, is entirely in his hands. The powers of the judge and the errors that he can make are two directly proportional quantities. The greater the powers entrusted to the judge, the greater the number of errors he can make $^{117}$. Great importance is therefore assumed by the remedies that the judicial system puts at the disposal of the party which suffers an invalid or unjust judgment.

Even though Sixteenth- and Seventeenth-century jurists know the distinction between error in law and error in fact of the judgment ${ }^{118}$, it is not upon this basis that they build the theory of the voidness of judgment. As we saw, the voidness of judgment derives instead from the fact that the error is expressed, manifest ${ }^{119}$. The voidness can be asserted notwithstanding the passing in rem judicatam and for a period of thirty years ${ }^{120}$.

The remedy given against a null and void judgment, that passed in rem judicatam, is elaborated by late ius commune and consists of the quaerela nullitatis ${ }^{121}$. If the quaerela nullitatis is allowed, it determines the rescission of the decision ${ }^{122}$. A considerable number of jurists suggests that it is not right to execute the res judicata affected by manifest voidness ${ }^{123}$. Together with them, there are those who affirm that the execution of the res judicata cannot be delayed by the excuse of its manifest voidness, because the presumption of truthfulness lies with the judgment ${ }^{124}$. It is perhaps not by chance that these words come from Gaill, assistant judge at the Reichskammergericht in the second half of the Sixteenth century and who recounts well the practices followed by this supreme court.

\section{Conclusion}

72 The power of judging and the duty to do it according to certain rules concentrate on the figure of the judge. The res judicata produces effects exactly because it is the result of the correct interaction between such power and such duty. The power of judging that the political order entrusts to the judge is limited by the fact that he has carried it out within the rules established by the same political order. The widening and narrowing of these limits have repercussions on the irrevocability - or better on the capacity of not being rescindable - of the res judicata which, in the most extreme hypothesis, could be valid and therefore produce its effects even in the case where the judge operates without respecting the rules ${ }^{125}$.

73 The res judicata is progressively constructed as an instrument whose purpose is to defend and keep the judging activity of the judge sound and to assess its legitimacy and validity against other forms of pacification which intervened between the parties. The res judicata is presented as the definitive remedy for solving conflicts. Even if private settlements still exist, they are gradually deprived of authority by the growing importance of the judge's decision, of which they are not any more a valid alternative. This great power entrusted to the judge must necessarily be regulated, and judges have to be careful in wielding it, in that they deal with questions concerning the innocence and guilt of a person. As Brunnemann says, the firmitas of the res judicata (meaning its irrevocability) cannot be extended to the point of harming the body and the fama of an 
innocent person, since the law did not give the judge the power to condemn or make an innocent person infamous ${ }^{126}$.

\section{BIBLIOGRAPHY}

Ahsmann, M., Matthaeus II. Antonius (1601-1654) (Wort), in Stolleis, M. (Hrsg.), Juristen. Ein biographisches Lexikon von der Antike bis zum 20. Jahrhundert, München, Verlag C.H. Beck, 1995a, p. 415.

Ahsmann, M., Wesenbeck Matthaeus (1531-1586) (Wort), in Stolleis, M. (Hrsg.), Juristen. Ein biographisches Lexikon von der Antike bis zum 20. Jahrhundert, München, Verlag C.H. Beck, 1995b, p. 651.

Alessi, G., Prova legale e pena. La crisi del sistema tra medio evo e moderno, Napoli, Jovene Editore, 1979.

Alessi, G., Il processo penale. Profilo storico, Roma-Bari, Laterza, 2001.

Ascheri, M.,I «Grandi Tribunali» d'Ancien Régime e la motivazione della sentenza, inAscheri, M., Tribunali, giuristi e istituzioni dal medioevo all'età moderna, Bologna, Il Mulino, 1989, pp. 85-183.

Baiardus, I.B., Additiones ad Iulii Clari Librum Quintum sive Practicam Criminalem, in Clarus, G., Liber Quintus sive Pratica Criminalis, Venetiis, ex typographia Baretiana, 1626.

Baldus de Ubaldis, In primam Digesti Veteris partem commentaria, Venetiis, apud Iuntas, 1577.

Bartolus a Saxoferrato, In Primam Digesti Novi partem ... (commentaria), Venetiis, apud Iuntas, 1580.

Beretta, C., Jacopo Menochio e la controversia giurisdizionale milanese degli anni 1596-1600, Archivio Storico Lombardo, 1977, III, pp. 47-128.

Bergfeld, Ch., Scaccia Sigismondo (16./17. Jh.) (Wort), in Stolleis, M. (Hrsg.), Juristen. Ein biographisches Lexikon von der Antike bis zum 20. Jahrhundert, München, Verlag C.H. Beck, 1995, p. 545.

Berlich, M., Decisiones aureae, Lipsiae, sumptibus viduae Gothofredi Grossi, 1656-1660.

Bertachinus, J., Repertorium, Venetiis, apud Nicolaum Bevilaquam \& socios, 1570.

Bettoni, A., Voci malevole. Fama, notizia del crimine e azione del giudice nel processo criminale (sec. XVI- XVII), Quaderni Storici, 2006, XLI, 1, pp. 13-38.

Birocchi, I., Alla ricerca dell'ordine, Torino, Giappichelli, 2002.

Boero, F.M., Fieschi e Doria: due famiglie per una città, Casale Monferrato, CEM, 1986.

Brunnemann, J., Consilia sive responsa academica, Francofurti ad Viadrum, sumptibus Jeremiae Schrey Heredorum \& Johannis Christophori Hartmann, 1704.

Brunnemann, J., De inquisitionis processu, Francofurti et Lipsiae, sumptibus Ioannis Christiani Kleibii, 1747a.

Brunnemann, J., De processu fori, Francofurti et Lipsiae, sumptibus Ioannis Christiani Kleibii, $1747 \mathrm{~b}$. 
Brunnemann, J., Commentarius in Quinquaginta libros Pandectarum, Coloniae Allobrogum, Sumptibus Fratrum Cramer, 1752.

Brunnemann, J., Commentarius in Codicem, Coloniae Allobrogum, sumptibus Fratrum Cramer, 1754.

Calamandrei, P., La teoria dell' «error in judicando» nel diritto italiano intermedio, Rivista critica di Scienze Sociali, 1914, I, nn.8/9-12, pp. 373-393, 437-471, 501-540 (now also in Calamandrei, P., Opere giuridiche, Napoli, Morano Editore, 1979, vol. VIII, pp.147-244).

Calcagno, D. (Ed.), I Fieschi tra papato ed impero. Conference proceedings, Lavagna, 18 December 1994, Chiavari, Grafica Piemme, 1998.

Calcagno, D. (Ed.), I Fieschi tra Medioevo ed Età Moderna. Proceedings of the conferences held on the occasion of the $450^{\text {th }}$ anniversary of the Fieschi plot, Genova, 21 October-2 Dicember 1997, Chiavari, Grafica Piemme, 1999.

Caroli, P., I manoscritti originali dei Consilia di Tiberio Deciani per la Repubblica di Genova, in Cavina, M. (Ed.), Tiberio Deciani (1509-1582). Alle origini del pensiero giuridico moderno, Udine, Forum, 2004, pp. 237-244.

Carpzov, B., Practica nova imperialis Saxonica rerum criminalium, Lipsiae, apud J.F. Gleditschium, 1739.

Casoni, F., Annali della Repubblica di Genova del secolo decimosesto, Genova, 1799.

Cassi, A.A., Testis pallidus. Indicazioni per un 'giusto processo' nel Tractatus di Deciani, in Cavina, M. (Ed.), Tiberio Deciani (1509-1582). Alle origini del pensiero giuridico moderno, Udine, Forum, 2004, pp. 141-156.

Cavanna Ciappina, M., Casoni Filippo, Dizionario Biografico degli Italiani, Roma, Istituto della Enciclopedia Italiana, 1978, 21, pp. 393-396.

Cavina, M. (Ed.), Tiberio Deciani (1509-1582). Alle origini del pensiero giuridico moderno, Udine, Forum, 2004.

Christynen, P. van, Practicarum quaestionum rerumque in supremis Belgicarum curiis ... decisiones, Antuerpiae, apud Hieronymum \& Io. Bapt. Verdussen, 1661.

Clarus, I., Sententiarum receptarum Liber Quintus, Venetiis, apud P.M. Bertanum, 1607.

Codics Domini Iustiniani Libri IX priores, Venetiis, apud Iuntas, 1592.

Constitutiones Papae Clementis V, Lugduni, apud Haeredes Gulielmi Rovillii, 1605.

Constitutiones criminales publicorum iudiciorum Caroli V, in Goldast von Heiminsfeld, M., Collectio constitutionum imperialium, Francofurti ad Moenum, ex officina Zunneriana, 1713, tome 3, pp. 516-560.

Cordero, F., Procedura penale, Milano, Giuffrè, 1985.

Costa,P., Iurisdictio. Semantica del potere politico nella pubblicistica medievale (1100-1433), Milano, Giuffrè, 1969.

Damaška, M.R., The faces of justice and State authority, New Haven, Yale University Press, 1986.

Damhouder, J. (but really Philippe de Wielant), Praxis rerum criminalium, Antuerpiae, sumptibus viduae et haeredum Ioan. Belleri, 1601.

Daoyz, S., Juris Civilis summa, seu index copiosus ..., Mediolani, Sumptibus J.B. Cetti, 1742.

Decianus, T., Responsa, Venetiis, apud Hieronymum \& Ioannem Zenarios, 1579, voll. 3. 
Decianus, T., Tractatus criminalis, Venetiis, apud Franciscum de Franciscis, 1590.

Decretum Gratianii [...] una cum glossis, Lugduni, sumptibus Petri Landry, 1606.

Decretales Papae Gregorii IX [...] una cum glossis, Lugduni, apud Haeredes Gulielmi Rovillii, 1606.

De Marsiliis, I., Practica criminalis, Venetiis, ex typographia Bartholomaei Rubini, 1574.

Digestum Novum seu Pandectarum Iuris Civilis tomus tertius, Venetiis, apud Iuntas, 1592.

Durand, B., Suspicion et récusation des juges dans le procès pénal d'Ancien Régime, Recueil de Mémoires et Travaux, publié par la Société d'Histoire du Droit et des Institutions des Anciens Pays de Droit Écrit, 1996, XVII (Critères du juste et contrôle des juges), pp. 91-128.

Falk, U., «In dubio pro amico». Lo studio di un caso di prassi consiliare e di trasmissione degli atti in Germania, Studi di storia del diritto, III (Università degli studi di Milano, Facoltà di Giurisprudenza, Pubblicazioni dell'Istituto di Storia del Diritto Italiano), Milano, 2001, pp. 389-417.

Falk, U., De la torture judiciaire en Saxe, en particulier chez Benedict Carpzov (1595-1666), in Durand, B. (Dir.), La torture judiciaire. Approches historiques et juridiques, Lille, Centre d'Histoire Judiciaire Éditeur, 2002, vol. 2, pp. 709-742.

Farinacius, P., Variae quaestiones et communes opiniones criminales, Venetiis, apud Io. Variscum et Paganinum de Paganinis, 1589.

Farinacius, P., Praxis et Theorica criminalis, Lugduni, sumptibus Iacobi Cardon, 1639.

Ferrer Beltrán, J., Prova e verità nel diritto, Bologna, Il Mulino, 2004.

Foucault, M., A verdade e as formas juridicas, Conferences held at the Pontifical Catholic University of Rio de Janeiro, from the $21^{\text {st }}$ to the $25^{\text {th }}$ May 1973, Cadernos da P.U.C., June 1974, 16, pp. 5-133 (Ital. Transl. Foucault, M., La verità e le forme giuridiche, Napoli, La città del Sole, 1994).

Gaill, A., Observationes practicae Imperialis Camerae, Augustae Taurinorum, apud Io. Dominicum Tarlnum, 1595.

Garnot, B., Intime conviction et erreur judiciaire. Un magistrat assassin au XVII ${ }^{e}$ siècle?, Dijon, EUD, 2004.

Griesebner, A., «In via gratiae et ex plenitudine potestatis». Grazia e prassi giudiziaria nell'Arciducato dell'Austria Inferiore (XVIII), in Nubola, C., Würgler, A. (Eds.), Suppliche e «gravamina». Politica, amministrazione, giustizia in Europa (secoli XIV-XVIII), Bologna, Il Mulino, 2002, pp. 307-342.

Groenewegen (van der Made), S., Tractatus de legibus abrogatis et inusitatis in Hollandia vicinisque regionibus, Amstelodami, apud Joannem Jassonium a Waesberge, 1669.

Guisius, I.A., De syndicatu, in Leyser, A., Meditationes ad Pandectas, Lipsiae, apud I. C. Meisnerum, 1762, vol. XI, specimen 680 .

Gunn, S., From hegemony to governmentality: changing conceptions of power in social history, Journal of Social History, 2006, XXXIX, 3, pp. 705-720.

Hanard, G., Res iudicata pro veritate habetur: la naissance d'un concept, Cahier du Centre de Recherches en Histoire du Droit et des Institutions, 1995, 4 (L'autorité de la chose jugée), pp. 15-28.

Harpprecht, J., Commentarius in quatuor institutionum iustinianearum libros, Francofurti, typis Iohannis Aubry, 1657. 
Härter, K., Negoziare sanzioni e norme: la funzione e il significato delle suppliche nella giustizia penale della prima età moderna, in Nubola, C., Würgler, A. (Eds.), Suppliche e «gravamina». Politica, amministrazione, giustizia in Europa (secoli XIV-XVIII), Bologna, Il Mulino, 2002, pp. 263-305.

Hewett, M., Hallebeek, J., The prelate, the praetor and the professor: Antonius Matthaeus II and the crimen laesae maiestatis, Utrecht 1639-1640, Tijdschrift voor Rechtsgeschiedenis, 1998, 66, pp. 115-150.

Holthöfer, E., Claro (Clarus) Giulio (1525-1575) (Wort), in Stolleis, M. (Hrsg.), Juristen. Ein biographisches Lexikon von der Antike bis zum 20. Jahrhundert, München, Verlag C.H. Beck, 1995a, pp. 128-129.

Holthöfer, E., Deciani (Decianus) Tiberio (1509-1582) (Wort), in Stolleis, M. (Hrsg.), Juristen. Ein biographisches Lexikon von der Antike bis zum 20. Jahrhundert, München, Verlag C.H. Beck, 1995b, pp. 164-165.

Holthöfer, E., Menocchio (Menochius), Jacopo (1532-1607) (Wort), in Stolleis, M. (Hrsg.), Juristen. Ein biographisches Lexikon von der Antike bis zum 20. Jahrhundert, München, Verlag C.H. Beck, 1995c, pp. 423-424.

Kempis, K.(von), Andreas Gaill (1526-1587). Zum Leben und Werk eines Juristen der frühen Neuzeit, Frankfurt am Main, Verlag Peter Lang, 1988.

Kleckner, W. H., Tiberio Deciani tra lesa maestà, ribellione e fellonia. (Le congiure dei Fieschi contro Sacro Romano Impero e alleati), in Cavina, M. (Ed.), Tiberio Deciani (1509-1582). Alle origini del pensiero giuridico moderno, Udine, Forum, 2004, pp. 257-279.

Langbein, J.H., Prosecuting crime in the Renaissance. England, Germany, France, Cambridge MA, Harvard University Press, 1974.

Langbein J.H., Torture and the law of proof. Europe and England in the Ancien Régime, Chicago, University of Chicago Press, 1976.

Leyser, A., De conceptione sententiae, in Leyser, A., Meditationes ad Pandectas, Lipsiae, apud I. C. Meisnerum, 1744, vol. VII, specimen 467.

Liber Sextus Decretalium Papae Bonifacii VIII, Lugduni, apud Haeredes Gulielmi Rovillii, 1605.

Luig, K., Leyser Augustin (1683-1752) (Wort), in Stolleis, M. (Hrsg.), Juristen. Ein biographisches Lexikon von der Antike bis zum 20. Jahrhundert, München, Verlag C.H. Beck, 1995, pp. 377-378.

Mancuso, F., Esprimere causam in sententia. Ricerche sul principio di motivazione della sentenza nell'età del diritto comune classico, Milano, Giuffrè, 1999.

Maranta, R. Quaestionum legalium disputationes decem, in Maranta R. Speculum aureum, Venetiis, apud Ioannem Mariam Bonellum, 1568a.

Maranta, R. Speculum aureum, Venetiis, apud Ioannem Mariam Bonellum, 1568b.

Marchetti, P., Testis contra se. L'imputato come fonte di prova nel processo penale dell'età moderna, Milano, Giuffrè, 1994.

Marongiu, A., Tiberio Deciani (1509-1582). Lettore di diritto, consulente, criminalista, Rivista di Storia del Diritto Italiano, 1934, 7, pp. 135-202, 312-387.

Massetto, G.P., Un magistrato e una città nella Lombardia spagnola. Giulio Claro pretore a Cremona, Milano, Giuffrè, 1985.

Massetto, G.P., Sentenza (diritto intermedio), Enciclopedia del Diritto, Milano, Giuffrè, 1989, vol. XLI, pp. 1200-1245. 
Massetto, G.P., La prassi giuridica lombarda nell'opera di Giulio Claro, in Massetto, G.P., Saggi di storia del diritto penale lombardo (secc. XVI-XVIII), Milano, Led, 1994a, pp. 11-59.

Massetto, G.P., I reati nell'opera di Giulio Claro, in Massetto, G.P., Saggi di storia del diritto penale lombardo (secoli XVI-XVIII), Milano, Led, 1994b, pp. 61-227.

Matthaeus, A., De criminibus, Trajecti ad Rhenum, typis Ioannis à Waesberge, 1644.

Mayali, L., Introduction, in Gouron, A., Mayali, L., Padoa Schioppa, A., Simon, D. (Hrsg.), Error iudicis. Juristische Wahrheit und justizieller Irrtum, Frankfurt am Main, Vittorio Klostermann, 1998, pp. 1-5.

Maynus, I., In primam Codicis Partem Commentaria, Venetiis, Aquilae renovantis insigne, 1590a.

Maynus, I., In primam Digesti Novi Partem Commentaria, Venetiis, Aquilae renovantis insigne, 1590b.

Mazzacane, A., Claro Giulio (voce), Dizionario Biografico degli Italiani, Roma, Istituto della

Enciclopedia Italiana, 1982, 26, pp. 141-146.

Mazzacane, A., Farinacci Prospero (voce), Dizionario Biografico degli Italiani, Roma, Istituto della Enciclopedia Italiana, 1995a, 26, pp. 1-5.

Mazzacane, A., Farinacci Prospero (1544-1618), in Stolleis, M. (Hrsg.), Juristen. Ein biographisches Lexikon von der Antike bis zum 20. Jahrhundert, München, Verlag C.H. Beck, 1995b, pp. 199-200.

Meccarelli, M., Arbitrium. Un aspetto sistematico degli ordinamenti giuridici in età di diritto comune, Milano, Giuffrè, 1998.

Menochius, I., De arbitrariis iudicum, Venetiis, ad signum Concordiae, 1590.

Menochius, I., Consilia sive Responsa, Venetiis, apud Io. Antonium \& Iacobum de Franciscis, 1609.

Métairie, G., La justice de proximité. Une approche historique, Paris, PUF, 2004.

Miletti, M.N., Stylus iudicandi. Le raccolte di decisiones del Regno di Napoli in età moderna, Napoli, Jovene, 1998.

Möller, E. (von), Julius Clarus aus Alessandria, der Kriminalist des 16. Jahrhunderts, der Rat Philipps II. 1525-1575, Aalen, Scientia Verlag, 1911.

Mollerus, D., Semestrium libri quinque, Lipsiae, impensis Henningi Grosi, 1631.

Mohnhaupt, H., Grundlinien in der Geschichte der Gesetzgebung auf dem europäischen Kontinent von 16. bis 18. Jahrhundert. Ein experimenteller Überblick, Zeitschrift für neuere Rechtsgeschichte, 2006, 28, 1/2, pp. 124-174.

Mynsinger, I., Singularium observationum iudicii Imperialis Camerae, in Gaill, A., Observationes practicae Imperialis Camerae, Augustae Taurinorum, apud Io. Dominicum Tarlnum, 1595.

Mynsinger, I., Responsa iuris sive consilia, Francofurti, in officina Poltheniana, 1601.

Mynsinger, I., Apotelesma, Lugduni, sumptibus Iacobi Cardon, 1632.

Otto, J., Carpzov, Benedikt (Wort), in Stolleis, M. (Hrsg.), Juristen. Ein biographisches Lexikon von der Antike bis zum 20. Jahrhundert, München, Verlag C.H. Beck, 1995a, pp. 115-116.

Otto, J., Gaill, Andreas (Wort), in Stolleis, M. (Hrsg.), Juristen. Ein biographisches Lexikon von der Antike bis zum 20. Jahrhundert, München, Verlag C.H. Beck, 1995b, pp. 220-221.

Padoa Schioppa, A., Ricerche sull'appello nel diritto intermedio, II. I glossatori civilisti, Milano, Giuffrè, 1970. 
Petracchi, A., Norma e prassi «costituzionale» nella serenissima Repubblica di Genova. I: la riforma del 1528, Nuova Rivista Storica, 1980a, LXIV, 1-2, pp. 43-80.

Petracchi, A., Norma e prassi «costituzionale» nella serenissima Repubblica di Genova. II: Modifiche al sistema: «Garibetto» e «Leges novae», Nuova Rivista Storica, 1980b, LXIV, 5-6, pp. 524-564.

Pifferi, M., Generalia delictorum. Il Tractatus criminalis di Tiberio Deciani e la «Parte generale» di diritto penale, Milano, Giuffrè, 2006.

Pinchard, B., Ricci, S. (Dir.), Rationalisme analogique et humanisme théologique. La culture de Thomas de Vio 'Il Gaetano'. Actes du Colloque de Naples $1^{\text {er }} 3$ novembre 1990, Napoli, Vivarium, 1993.

Pistarino, G. (Ed.), Il tramonto dei Fieschi e la caduta del castello di Montoggio. Conference proceedings, Montoggio, 30 August 1997, Genova, Accademia Ligure di Scienze e Lettere, 2001.

Pozo, L.M., The mechanism of class accommodation in precapitalist Europe: a study in hegemony, Review, 2006, XXXIX, 3, pp. 227-269.

Raggio, O., Fieschi, Gian Luigi (voce), Dizionario Biografico degli Italiani, Roma, Istituto della Enciclopedia Italiana, 1997, 47, pp. 462-464.

Rawls, J., A theory of justice, Cambridge MA, Belknap Press of Harvard University Press, 1971.

Resta, E., La verità e il processo, Politica del Diritto, 2004, XXXV, 3, pp. 369-408.

Robaye, R., L'autorité de la chose jugée ou le droit entre universel et particulier, Cahier du Centre de Recherches en Histoire du Droit et des Institutions, 1995, 4 (L'autorité de la chose jugée), pp. 7-14.

Rosoni, I., Quae singula non prosunt collecta iuvant. La teoria della prova indiziaria nell'età medievale e moderna, Milano, Giuffrè, 1995.

Savelli, M.A., Summa diversorum tractatuum, Venetiis, ex typographia Balleoniana, 1748.

Savelli, R., La Repubblica oligarchica. Legislazione, istituzioni e ceti a Genova nel Cinquecento, Milano, Giuffrè, 1981.

Savelli, R., Il problema della giustizia a Genova nella legislazione di primo Cinquecento, in Bianchini, M. G., Viarengo, G. (Eds.), Studi in onore di Franca de Marini Avonzo, Torino, Giappichelli, 1999, pp. 329-350.

Sbriccoli, M., Crimen laesae maiestatis. Il problema del reato politico alle soglie della scienza penalistica moderna, Milano, Giuffrè, 1974.

Sbriccoli, M., «Vidi communiter observari». L'emersione di un ordine penale pubblico nelle città italiane del secolo XIII, Quaderni Fiorentini per la storia del pensiero giuridico moderno, 1998, 27, pp. 231-268.

Sbriccoli,M., Giustizia negoziata, giustizia egemonica. Riflessioni su una nuova fase degli studi di storia della giustizia criminale, in Bellabarba, M., Schwerhoff, G., Zorzi, A. (Eds.), Criminalità e giustizia in Germania e in Italia. Pratiche giudiziarie e linguaggi giuridici tra tardo medioevo ed età moderna, Bologna, Il Mulino, 2001, pp. 345-364 (also in Bellabarba M., Schwerhoff G., Zorzi A. (Hrsg.), Kriminalität und Justiz im Deutschland und Italien. Rechtspraktiken und gerichtliche Diskurse in Spätmittelalter und Früher Neuzeit, Berlin, Duncker \& Humblot).

Sbriccoli, M., Giustizia criminale, in Fioravanti, M., Lo Stato moderno in Europa. Istituzioni e diritto, Roma-Bari, Laterza, 2002, pp. 163-205. 
Sbriccoli, M., Lex delictum facit. Tiberio Deciani e la criminalistica italiana nella fase cinquecentesca del penale egemonico, in Cavina, M., Tiberio Deciani (1509-1582). Alle origini del pensiero giuridico moderno, Udine, Forum, 2004, pp. 91-119.

Scaccia, S., De sententia et re judicata, Venetiis, apud Paulum Baleonium, 1669.

Schild, W. (Hrsg.), Benedikt Carpzov 1595-1666. Werk \& Wirken, Goldbach, Keip Verlag, 1997.

Schrage, E.J.H, The judge's liability for professional mistakes, The Journal of Legal History, 1996, XVII, 2, pp. 101-129.

Schubart-Fikentscher, G., Berlichius Matthias, (Wort), Handwörterbuch zur deutschen Rechtsgeschichte, Berlin, Erich Schmidt Verlag, 1971a, band I, col. 381.

Schubart-Fikentscher, G., Carpzov Benedikt, (Wort), Handwörterbuch zur deutschen Rechtsgeschichte, Berlin, Erich Schmidt Verlag, 1971b, band I, coll. 595-597.

Schubart-Fikentscher, G., Harpprecht Johannes Friedrich, (Wort), Handwörterbuch zur deutschen Rechtsgeschichte, Berlin, Erich Schmidt Verlag, 1971c, band I, coll. 2008-2010.

Sellert, W., Gail (Gaill, Geyl, Gayle), Andreas, (Wort), Handwörterbuch zur deutschen Rechtsgeschichte, Berlin, Erich Schmidt Verlag, 1971b, band I, coll.1371-1373.

Spierenburg, P., The spectacle of suffering, Cambridge, Cambridge University Press, 1984.

Stryk, S., Usus modernus Pandectarum, in Stryk, S., Opera omnia, Florentiae, apud Josephum Celli, 1841, vol. XV.

Theodoricus, P., Iudicium criminale practicum, Jenae, typis Johannis Nisi, 1671 [anast. Goldbach, Keip Verlag, 1996].

Thomas de Vius (Caietanus), Commentarii in Summam Theologicam S. Thomae de Aquino, in Tommaso d'Aquino, Opera omnia, Romae, ex typographia Polyglotta S. C. De Propaganda fide, 1897, vol. 9: Secunda secundae Summae Theologiae: a quaestione 57. ad quaestionem 122.

Tudeschus N. (Abbas Panormitanus), In Quartum et Quintum Librum Decretalium ... (commentaria), Venetiis, apud Iuntas, 1588.

Tuschus, D., Practicae conclusiones iuris, Lugduni, Sumptibus. Borde P., Arnaud L., Rigaud L., 1661.

Valsecchi, C., L' istituto della dote nella vita del diritto del tardo Cinquecento: $\mathrm{i}$ "consilia» di Jacopo Menochio, Rivista di Storia del Diritto Italiano, 1994, LXVII, pp. 205-282.

Valsecchi, C., Jacopo Menochio e il giurisdizionalismo tra Cinque e Seicento, Studia Borromaica, 2000, 14, pp. 93-113.

Voet, J., Commentarius ad Pandectas, Hagae-Comitum, apud Petrum de Hondt, 1731.

Walters, D., The significance of the rule res iudicata pro veritate accipitur in the Common Law and some comparison with the equivalent rules of droit savant, Cahier du Centre de Recherches en Histoire du Droit et des Institutions, 1995, 4 (L'autorité de la chose jugée), pp. 63-73.

Wesenbeck, M., Responsa iuris quae vulgo consilia appellantur, Basileae, apud Eusebium Episcopium, 1579.

Wesenbeck, M., In Pandectas iuris civilis et Codicis Iustinianei libros commentarii olim Paratitla dicti, Patavii, typis Pauli Frambotti, 1658.

Zasius,U.,Commentaria, seu lecturas eiusdem in titulos tertiae Pandectarum partis, in Zasius, U., Opera omnia, Lugduni, apud Sebastianum Gryphium, 1550, [anast. Aalen, Scientia Verlag, 1964], vol. 3. 


\section{NOTES}

2. Rawls (1971, p. 3).

3. Casoni (1799, V, II, p.157). Casoni wrote his Annali in 1692 and they were published in 1708. Concerning Filippo Casoni see Cavanna Ciappina (1978, pp. 393-396).

4. The plot of the Fieschi has been the subject of many historical interpretations since its happening. Historians and novelists dealt with it repeatedly. Among the most recent works we remember Boero (1986); Raggio (1997); Calcagno (1998, 1999); Pistarino (2001).

5. The reform of 1528 gives birth to many institutional and political problems which will trouble the life of the Genoese Republic for many decades. On the matter see Petracchi (1980a, pp. 43-80); Savelli (1981, pp. 39-79, 1999).

6. From the Fifteenth to the Eighteenth century during the Spanish domination, the contract of asiento is stipulated between a Sovereign and an individual or a group of individuals who commit themselves to permanently keep a certain number of ships ready and armed for the purpose of war.

7. On the crime of lese-majesty see Sbriccoli (1974).

8. Kleckner (2004, p. 264).

9. Notices about all the consilia can be found in Kleckner (2004, p. 259, footnotes n. 13 and 15 and pp. 260-261, footnotes n. 20, 2122,24 ).

10. Decianus (1579, vol. 1 , consilium 18, numbers 1 to 288 deal with the exceptions of voidness, numbers 289 to 393 are concerned with the crime of lese-majesty). A detailed analysis of Decianus's consilium can be found in Caroli (2004) and Kleckner (2004). Tiberius Decianus (1509-1582) is professor of Criminalia at the University of Padua and is consultant in iure of the Venetian Republic. He writes a Tractatus criminalis renowned for its generalia delictorum, and a collection of responsa in five volumes. He plays a politically important role in founding the criminal law upon legislation. On Decianus see Marongiu (1934); Holthöfer (1995b); Cavina (2004); Pifferi (2006).

11. Menochius writes five consilia $(1609$, lib. 1 , consilia $99,100,101,102,103)$ for the Genoese Republic dealing with the Fieschi case. Consilium 100, to which we refer here, is dedicated to the matter concerning the exceptions of voidness. Iacobus Menochius (1532-1607) is professor of Institutiones at the University of Pavia, of Ecclesiastical law at the University of Mondovì and of Civil law at the University of Padua where Decianus is among his colleagues. His counselling activity is as important as his academic activity, and his collection of consilia and responsa in thirteen volumes is widely known and a good help for law practicians. On Menochius see Beretta (1977); Holthöfer (1995c); Valsecchi (1994, 2000); Birocchi (2002, pp. 244-245).

12. For a comparison between the significance of res judicata in common law and ius commune, see Walters (1995).

13. Rosoni (1995, pp. 299-311, especially p. 305).

14. Sbriccoli (1998, pp. 245-246) speaks of "proactivity" of judicial apparatuses, meaning that, when a crime is committed, they have the capacity of "acting" without any further input in order to guarantee public order and pax civitatis. Sbriccoli borrowed the category of "proactivity" from Damafka (1986, chap. 3) adapting it to the early modern period.

15. Sbriccoli (2001). Langbein (1974, p. 146), agreeing with a thesis of Schmidt, affirms that during the Fourteenth and Fifteenth century «Offizialprinzip and Instruktionsmaxime became commonplace in Germany; with them Inquisitionsprozess had arrived».

16. Gunn (2006, p. 707). For a definition of "hegemony" in precapitalist Europe see Pozo (2006).

17. Sbriccoli (2002, p. 167). On the 'emergence of public penal law' see Langbein (1974, pp. 140-155); Spierenburg (1984, pp. 1-12); Foucault (1994, pp. 79-94). Métairie (2004 pp. 29-30) for the French kingdom speaks of a proces of institutionalization of justice. 
18. Digestum Novum 42, 1 (De re iudicata et de effectu sententiarum, et de interlocutionibus); Digestum Novum 44, 2 (De exceptione rei iudicatae); Codex 2, 26 (Si adversus rem iudicatam restitutio postuletur); Codex 7, 52 (De re iudicata); Codex 7, 53 (De executione rei iudicatae); Codex 7, 54 (De usuris rei iudicatae); Codex 7, 56 (Quibus res iudicata non nocet); Codex 7, 57 (Comminationes, epistolas, programmata, subscriptiones authoritatem rei iudicatae non habere); Codex 7, 60 (Res inter alias actas vel iudicatas aliis non nocere).

19. Decretum Gratianii, pars 2, causa 35, quaestio 9; Decretales Papae Gregorii IX, 2, 27 (De sententia et re iudicata); Liber Sextus Decretalium Papae Bonifacii VIII, 2, 14 (De sententia et re iudicata); Constitutiones Papae Clementis V, 2, 11 (De sententia et re iudicata).

20. Carpzov (1739, pars 3, quaestio 106, n. 2) openly declares it.

21. Harpprecht (1657, tomus 4, lib. 4, tit.17 De officio iudicis, § 7 Quod autem, nn. 16-22); Mynsinger (1632, lib. IV, tit. 13 Exceptiones, $\S 4$ De re iudicata, nn. 1, 2); Wesenbeck (1658, lib. 42, tit. 1 De re iudicata et de effectu sententiarum, nn. 3-4, 8); Scaccia (1669, glossa 14, quaestio 2, n. 1).

22. Zasius (1550, lib. 42, tit.1 De re iudicata, lex 1 Res iudicata, n. 6); Harpprecht (1657, tomus 4, lib. 4, tit. 17 De officio iudicis, § 7 Quod autem, nn. 16-17); Gaill (1595, lib. I, observatio 109, nn. 1,2,3,8); Maranta (1568b, pars VI Et demum fertur sententia, Decisoria iudicii, tribus membris distinta: nempe sententia, appellatione et executione, actus I, nn. 1-29); Brunnemann (1747b, cap. XXVII, De sententiae conceptione, nn. 1, 28); Scaccia (1669, glossa 14, quaestio 4, n. 1, quaestio 28, nn. 9-12). To the final judgment jurists equate the interlocutory judgment when it has characteristics which attribute force of final judgment to it. Usually that is what happens when: «per illam non diffinitur integre causa principalis, sed per indirectum tangitur, et definitur articulus, qui ad diffinitivam spectat ... quando per illam expirat iudicis officium ... Istis duobus modis sententia interlocutoria vim diffinitivae obtinet: adde pro tertio modo, si post interlocutoriam non speratur alia sententia, ut in absolutione ab observatione iudicii: aut pro quarto modo, quando interlocutoria continet aliquid dari, vel fieri» Gaill (1595, lib. I, observatio 130, n. 6).

23. There are different opinions on the res judicata and the passing in rem judicatam in the Thirteenth and Fourteenth centuries. Bartolus a Saxoferrato $(1580$, lib. 42, tit.1 De re iudicata, lex 1 Res iudicata, n. 1) distinguishes between judgment and res judicata and declares that the judgment is res judicans, that is, it is the act of judging that actively puts an end to the dispute, while the res judicata is the case itself, which passively receives its conclusion from the judgment. Therefore, judgment and res judicata are two distinct institutes for the jurist and they come about at the same time. The canonists take up a different position (at the basis of their opinion is: Decretales Papae Gregorii IX, 2, 27 De sententia et re iudicata, cap. 15 Quod ad consultationes) and hold that judgment and res judicata are both the same thing considered at two distinct moments in time: the judgment is so called when it concludes the case, it passes in rem judicatam following the ten days' time for appeal. It is the canonists that elaborate the notion of passing in rem judicatam of the judgment, who give value and meaning to the time for appeal spent uselessly, and who do not permit settlement on the res judicata. Between the end of the Fifteenth century and the beginning of the Sixteenth, the opinio Bartoli is, once and for all, criticised and laid to one side. Author of the tranchant criticism which leaves no room for doubt upon which of the two opinions has prevailed, is Iason Maynus (1590b, lib. 42, tit. 1 De re iudicata, lex 1 Rex iudicata, nn. 7-8). The opinion of the canonists will affirm itself extensively among ius commune jurists and will, therefore, get the better of Bartolus's.

24. Wesenbeck (1658, lib. 42, tit. 1 De re iudicata et de effectu sententiarum, n. 8); Harpprecht (1657, tomus 4, lib. 4, tit. 17 De officio iudicis, § 7 Quod autem, n. 21); Scaccia (1669, glossa 14, quaestio 2, nn. 3-4).

25. Clarus (1607, § finalis, quaestio 94, n. 1 in fine); Damhouder (1601, cap. 151 De Appellatione,nn. 1-2).

26. Padoa Schioppa (1970, p. 73) points out a tendency to sensibly reduce the application range of the appeal in criminal trial since the Thirteenth century. 
27. Theodoricus (1671, tomus II, cap. X De poenis, aphorismus 5, litera d, n. 55).

28. De Marsiliis (1574, § Opportune, n. 6 circa in medio, nn. 62-63); Baiardus (1626, § finalis, quaestio 94, n. 29).

29. Constitutiones criminales publicorum iudiciorum Caroli V (1713).

30. The doctrine accepts the principle: Gaill (1595, lib. I, observatio 1, nn. 27-28);Mynsinger (1595, centuria II, observatio 98);Theodoricus (1671, tomus II, cap. X De poenis, aphorismus 5, litera d, n. 55); Harpprecht (1657, tomus 4, lib. 4, tit. 18 De publicis iudiciis, principium tituli, nn. 20-21); Carpzov (1739, pars 3, quaestio 139, n. 37). Damhouder (1601, cap. 151 De Appellatione, nn. 3-4), affirms that the same principle also operates in Flanders.Baiardus (1626, § finalis, quaestio 94, n. 31) sustains that appeal is permitted throughout France. On the appeal in France see Alessi (2001, pp. 111-112 and all chapter 3: Appello: le grandi ordinanze d'età moderna, pp. 65-118).

31. Article 219 of the CCC entitled: Clarification from whom and in which places advice shall be sought: «Since in many places previously in this our and the holy Empire's criminal courts ordinance the seeking of advice has been spoken of, it is therefore required that all criminal courts, when they find themselves in doubt as to their criminal procedure, court practices, and sentences, be obliged to seek advice of their superior courts (Oberhöfe), those from whom they have previously been advised according to ancient usage. Those, however, which have no superior court shall, in cases in which the court proceeding has been carried out upon the demand of a criminal law complainant, seek advice of their authorities who are empowered to conduct the said criminal court ex officio and without intervention. When, however, the authorities ex officio bring criminal complaint or proceedings against a criminal, the judges (where they find themselves in doubt) are obliged to seek advice from the nearest universities (hohen Schulen), cities, free cities, or others legally knowledgeable there where they think the information is obtainable at the least cost. And it is particularly to be noticed that in all doubtful cases not merely Schöffen and judgement-givers themselves, but also anyone who is supposed to deal with and to advise such authorities in criminal matters, shall take the advice of the legally knowledgeable without cost to the parties. When, however, a penal complainant has petitioned the judge to seek the advice of the legally knowledgeable in the particular criminal proceeding and practice, it shall take place at the cost of the petitioning side. When, however, the master, friend, or counselor of the prisoner requests for his benefit similar advice-seeking of the judge, he shall oblige at the cost of the friends or counselor of the prisoner. Where, however, the friends of the said prisoner are unable, on account or poverty, to bear the aforesaid costs, then the said judge shall be bound to pursue this advice at the cost of the autorities; but only to the extent he has not observed that the advice-seeking is occurring intentionally to the protraction of matters or in order to create more costs (which the aforementioned friends or counselors shall also affirm upon their oaths); thus shall no conceivable effort be spared, lest otherwise denial of justice happen to anyone; for to these great matters great effort is appropriate, because regarding such transgressions, ignorance on the part of those who ought in fact to know will not excuse - concerning which judges, Schöffen, and the said authorities shall be hereby cautioned ». The English translation of article 219 of the CCC is contained in Appendix B of Langbein (1974, pp. 307-308). Appendix B contains the translation into English of all the criminal procedural articles of the CCC.

32. Brunnemann (1747a, cap. XI De contrariis, quae contra inquisitionem opponi possunt, n. 19). Johann Brunnemann (1608-1672) is a professor at the University of Frankfurt-am-Oder. His Commentarii on the Pandectae and Codex of Justinian's Corpus Juris Civilis are well known. In 1674 Samuel Stryk, one of his pupils and his son-in-law, publishes the second edition of Brunnemann's Commentarius in quinquaginta libros Pandectarum (first published in 1668) adding many leges that were missing in the first edition. On Brunnemann, please see the incipit of his works.

33. Berlich (1656-1660, pars 2, decisio 231). Matthias Berlich (1586-1638) is a jurist of a certain importance. He is a lawyer and a professor at the University of Leipzig. His works have a great 
circulation in Germany and are often quoted. Carpzov is his pupil and the influence over his disciple is such that the adage: «Nisi Berlichius berlichizasset, Carpzovius non carpzoviasset» (If Berlich had not existed, Carpzov would have not existed either) is well spread in Leipzig. About the life and work of Berlich please see Schubart-Fikentscher (1971a). Berlich's opinion is shared by two other Saxon jurists: Theodoricus (1671, tomus II, cap. X De poenis, aphorismus 5, litera d, nn. 55 in fine and 56); Mollerus (1631, lib. 4, sem. 34, n. 5).

34. Theodoricus (1671, tomus II, cap. X De poenis, aphorismus 5, litera d, n. 56). Peter Dietrich (Petrus Theodoricus) (1580-1640) is promoted professor of law at the faculty of Jurisprudence in Jena (Electoral Saxony) in 1606. He writes his Judicium criminale practicum in 1616. Dietrich is basically an academic and his Iudicium, whose style and content are inspired by the Tractatus criminalis of Decianus, contains the generalia delictorum in its first chapter, accepting - in such a way - the methodological challenge of Decianus's Tractatus. On Dietrich, see the incipit of his work and Pifferi (2006, pp.188-194).

35. Carpzov (1739, pars 3, quaestio 107, n. 37, quaestio 139, n. 45). Benedikt Carpzov (1595-1666) is professor at the Faculty of Jurisprudence and primus ordinarius (president) of the Schöffenstuhl (Echevin Court) in Leipzig. He was one of the main interpreters of the Usus Modernus Pandectarum and an eminent criminalist. His Practica nova Imperialis Saxonica rerum criminalium (1635) acquires great fame and is still printed in 1752. The Practica brings in a milding trend in criminal justice especially as far as the application of the death sentence in all cases provided for by the CCC is concerned. On Carpzov see Schubart Fikentscher (1971b); Otto (1995a); Schild (1997); Falk (2002).

36. Carpzov (1739, pars 3, quaestio 116, nn. 11-19).

37. On the jurists' debate concerning the controversial role of the transmission of acts in the German area see Falk (2001).

38. Carpzov (1739, pars 3, quaestio 116, n. 20). On the transmission of judicial acts for other German regions see alsoBrunnemann (1747a, cap. VIII De defensione actorum, membrum 4 De transmissione actorum inquisitionalium) for the Brandenburg region; Harpprecht (1657, tomus 4, lib. 4, tit. 17 De officio iudicis, principium, nn. 27-28) for the Württemberg region.

39. Carpzov (1739, pars 3, quaestio 139, nn. 37-41). In the quoted passage Carpzov affirms that this is what he can see practised everyday in the Echevin Courts.

40. Clarus (1607, § finalis, quaestio 94, n. 3). Iulius Clarus (1525-1575) is a judge in the Senato (High Court) of Milan and a well known criminalist. He writes the Liber quintus of his Sententiae receptae in 1568. In it Clarus deals with criminal law, while in its last paragraph he estensively treats the criminal judicial procedure. He is well aware of the noteworthy importance of the judicial precedent in the effective law which does not and cannot consist only in the ius commune and in the statutes and constitutions. On Clarus see Möller (1911); Mazzacane (1982); Massetto (1985, 1994ab); Holthöfer (1995a); Birocchi (2002, pp. 257-261).

41. Menochius (1590, lib. 1, quaestio 52, nn. 15-16).

42. Farinacius (1639, pars 1, quaestio 101, n. 113). The atrocious crimes listed in the quoted passage are: violence, kidnapping, counterfeiting, sedition, lese majesty, murder, robbery, heresy, simony. Prosperus Farinacius (1544-1618) is a lawyer and a judge of the Camera Apostolica and Sacra Consulta. He has an extensive knowledge of criminal matters - deriving also from personal experience - and an extraordinary ability in defending his clients. His Praxis et Theorica criminalis (1614) is a huge deposit of argumentations ready to be used by practicians. On Farinacius see Mazzacane (1995a, b); Birocchi (2002, pp. 267-269).

43. Baiardus (1626, § finalis, quaestio 94, nn. 30-32). Ioannis Baptista Baiardus (d. at the end of the 16th century) gets his degree in utroque iure at the University of Parma and from 1566 to 1569 is governor of Narni and Spoleto. In 1598 he publishes his Additiones to Clarus's Sententiarum Libri.

44. Gaill (1595, lib. I, observatio 42, n. 5); Brunnemann (1747b, cap. I, De processu in genere, n. 26).

45. Carpzov (1739, pars 3, quaestio 139, n. 38 in fine).

46. Carpzov (1739, pars 3, quaestio 137, nn. 11-31). 
47. See for example De Marsiliis (1574, § Opportune, nn. 6-33); Farinacius (1589, liber I, quaestio11, n. 62 circa in medio);Brunnemann (1747a, cap. X, De executione sententiae condemnatoriae, n. 6 , see also nn. 1-10); Carpzov (1739, pars 3, quaestio 137, n. 18).

48. Wesenbeck (1658, lib. 42, tit. 1 De re iudicata et de effectu sententiarum, n. 8 circa in medio);Gaill (1595, lib. I, observatio 144, n. 6); Tuschus (1661, VI, conclusio 267, Res iudicata quando pro veritate habeatur, vel non et quae sit ratio, n. 43); Brunnemann (1747b, cap. XXVII, De sententiae conceptione, n. 62); Scaccia (1669, glossa 14, quaestio 2, n. 9, quaestio 12, n. 1). On the concept of res judicata as particular rule see Robaye (1995).

49. Zasius (1550, lib. 42, tit.1 De re iudicata, lex 63 Saepe, n. 11); Mynsinger (1601, decas 13, responsum 2, n. 186); Wesenbeck (1658, lib. 42, tit. 1 De re iudicata et de effectu sententiarum, n. 8 circa in medio); Brunnemann (1747b, cap. XXVII, De sententiae conceptione, nn. 73-75); Scaccia (1669, glossa 14, quaestio 12, nn. 63-130). Scaccia affirms at n. 121 of the quoted quaestio that eventhough the final judgment cannot harm third parties, nevertheless it can cause them certain damage because of ties and dependence. For this reason, adds the jurist, the possibility of appealing against the judicial decision is provided for on their behalf.

50. Christynen (1661, vol. 2, decisiones 51, 63, vol. 4, decisio 87);Daoyz (1742, pars II, ad verbum: sententia, n. 56 in fine).

51. Mynsinger (1601, decas 13, responsum 2, n. 124) affirms: «Adeo ut hodie apud Germanos omnis illa controversia debeat esse sopita, ac si lege aliqua esset decisa, cum sententia supremi iudicis ad instar Principis vim et auctoritatem legis habeat». On the question see also: Harpprecht (1657, tomus I, lib. 1, tit. De iure naturali gentium et civili, § 3 Constat autem, n. 8); Savelli (1748, tomus 4, § Opinio, n. 4). The question is briefly mentioned in Calamandrei (1979, vol. VIII, p. 170); and in Birocchi (2002, p. 95). It is extensively treated in Massetto (1989, pp. 1203-1224) and in Mohnhaupt (2006, pp. 160-164).

52. Maynus (1590a, lib. 2, tit. 4 De transactionibus, lex 16 Causas vel lites, nn. 3-7); Brunnemann (1754, tomus II, lib. 7, tit.50 Sententiam rescindi non posse, lex 3 Impetrata, n. 1).

53. On this point see Birocchi (2002, pp. 85-93); Miletti (1998); Ascheri (1989, p. 92).

54. Maynus (1590b, lib. 42, tit. 1 De re iudicata, lex 1 Res iudicata dicitur, n. 15); Harpprecht (1657, tomus 4, lib. 4, tit. De exceptionibus, § 5 Item si in iudicio, nn. 1-5); Mynsinger (1632, lib. IV, tit. 13 Exceptiones, § 4 De re iudicata, nn. 3-9); Tuschus (1661, VI, conclusio 266, Res iudicata operatur multa et habes diversos effectus, nn. 7,8,10); Farinacius (1639, pars 1, quaestio 4, nn. 1-3);Brunnemann (1747a, cap. VI, De personis contra quas formanda est inquisitio, nn. 2-9); Brunnemann (1754, tomus II, lib. 7, tit.50 Sententiam rescindi non posse, lex 1 Neque suam, nn. 1-4);Voet (1731, tomus II., lib. XLIV, tit. 2 De exceptione rei judicatae, nn. 1-8). Brunnemann (1747b, cap. XXVII, De sententiae conceptione, $\mathrm{n} .72$ ) states that the defendant cannot plead against the res judicata if he has been acquitted for lack of evidence. On the ne bis in idem principle see also Ferrer Beltrán (2004, pp. 67-68).

55. Zasius (1550, lib. 42, tit.1 De re iudicata, lex 63 Saepe, n. 68); Maranta (1568b, pars VI Et demum fertur sententia, Decisoria iudicii, tribus membris distinta: nempe sententia, appellatione et executione, actus I, n. 119); Menochius (1590, lib. 1, quaestio 52, n. 2); Tuschus (1661, VI, conclusio 266, Res iudicata operatur multa et habes diversos effectus, nn. 7,8,10);Daoyz (1742, pars II, ad verbum: sententia, n. 46); Brunnemann (1754, tomus II, lib. 7, tit.50 Sententiam rescindi non posse, lex 1 Neque suam, nn. 1-4);Savelli (1748, tomus 4, § Sententia, n. 23).

56. Daoyz (1742, pars II, ad verbum: sententia, n. 46).

57. Matthaeus (1644, lib. 48, tit.18, cap. 3, n. 7 circa in medio). Antonius Matthaeus (1601-1654) is professor of law at the University of Utrecht. He writes his De criminibus in 1644. Matthaeus bases it on books 47 and 48 of the Digest also known as libri terribiles. He interprets the leges contained in them and adds a concise analysis of the municipal law of Utrecht at the end of every title of theirs. On Matthaeus see Ahsmann (1995a); Hewett, Hallebeek (1998).

58. Farinacius (1639, pars 1, quaestio 4, n. 4). On the point see Pifferi (2006, pp. 126-143). 
59. Daoyz (1742, pars II, ad verbum: res, n. 14).

60. Clarus (1607, § finalis, quaestio 58, n. 1 versic. Sequens, and n. 2 versic. Sed punctus). On the point Baiardus (1626, § finalis, quaestio 58, additio at Parum prodesset), declares that in the Papal States settlements are permitted only in case of light offenses like verba iniuriosa (verbal offences), pugna (fight). On settlements in criminal matters see Sbriccoli (2004, pp. 110-111).

61. Carpzov (1739, pars 3, quaestio 148, nn. 1-18).

62. Brunnemann (1747a, cap. VI, De personis contra quas formanda est inquisitio, nn. 12-14).

63. Brunnemann (1747a, cap. IV, De causis impulsivis inquisitionis, n. 38). In the civil proceeding the intervened settlement between the parties allows them to plead against demurrer (exceptio peremptoria) during the trial. On the point see Brunnemann (1754, tomus II, lib. 7, tit.50 Sententiam rescindi non posse, lex 2 Peremptorias, nn. 1-4).

64. Wesenbeck (1579, cons.70, n. 12): «Quod ad secundam dubitationem attinet, videtur non potuisse transigi super re iudicata ... Nam res iudicata iam certa est per sententiam ... Transactio autem fit super dubiis, non certis ... Sed hoc accipiendum est per modum transactionis, ut aliquid pro remissione detur, ... non recte transigi super re iudicata, sicut nec iudicatur, cum nulla subsit talis remissionis causa». Matthaeus Wesenbeck (1531-1586) is professor of law at the University of Wittenberg and judge at the local Schöffenstuhl (Echevin Court). He basically works on Justinian's Pandectae and in 1566 publishes his Paratitla in Pandectarum iuris civilis libros quinquaginta which, a century later, will be reprinted with Brunnemann's commentary. In 1576, he writes Tractatus et responsa quae vulgo consilia appellantur which is the result of his work as law practician. On Wesenbeck see Ahsmann (1995b). On settlement and res judicata see alsoZasius (1550, lib. 42, tit.1 De re iudicata, lex 4 Si se non obtulit, § 3 Ait praetor, nn. 1-5).

65. Brunnemann (1747a, cap. VI, De executione sententiae condemnatoriae, nn. 2-9).

66. Maynus (1590b, lib. 42, tit. 1 De re iudicata, lex 1 Res iudicata dicitur, n. 8);Tuschus (1661, VI, conclusio 267, Res iudicata quando pro veritate habeatur, vel non et quae sit ratio, n. 57); Brunnemann (1752, tomus II, lib. 42, tit.7 De re judicata, lex 35 Imperatores, nn. 1-7); Scaccia (1669, glossa 14, quaestio 2, n. 6).

67. Zasius (1550, lib. 42, tit.1 De re iudicata, lex 56 Post rem, n. 1, lex 61 In iudicati, n. 1); Maranta (1568b, pars VI Et demum fertur sententia, Decisoria iudicii, tribus membris distinta: nempe sententia, appellatione et executione, actus III, nn. 1-2); Gaill (1595, lib. 1, observatio 113, n. 16);Wesenbeck (1658, lib. 42, tit. 1 De re iudicata et de effectu sententiarum, n. 9);Theodoricus (1671, tomus II, cap. X De poenis, aphorismus 5, litera g). Harpprecht (1657, tomus 4, lib. 4, tit.17 De officio iudicis, § 7 Quod autem, nn. 23-26). De Marsiliis (1574, § Opportune) indicates the ways that can be followed in order to respite the execution of the capital sentence passed inrem judicatam or which cannot be appealed any more.

68. Tuschus (1661, VI, conclusio 267, Res iudicata quando pro veritate habeatur, vel non et quae sit ratio, n. 65); similarly Brunnemann (1747b, cap. XXIX, De rei judicatae executione, n. 1). About the criminal judicial system established by the Constitutio Criminalis Carolina which does not provide for appeal, Carpzov (1739, pars 3, quaestio 137, n. 1) states that the execution of the sentence follows the final judgment and cannot be performed if a law order is lacking.

69. Maynus (1590b, lib. 42, tit. 1 De re iudicata, rubrica, nn. 1-2);Menochius (1590, lib. 1, quaestio 52, n. 3); Tuschus (1661, VI, conclusio 267, Res iudicata quando pro veritate habeatur, vel non et quae sit ratio, nn. 54-56, 79);Daoyz (1742, pars II, ad verbum: sententia, n. 56); Scaccia (1669, glossa 14, quaestio 2, n. 7 in fine); Savelli (1748, tomus 4, § Sententia, n. 34).

70. Rosoni (1995, pp. 158-159) explains that this type of presumptions is called iuris, because is introduced by the law, and de iure, because the law itself makes them the basis of an indisputable right.

71. Rosoni (1995, p. 159). 
72. Wesenbeck (1658, lib. 42, tit. 1 De re iudicata et de effectu sententiarum, n. 8);Gaill (1595, lib. 1, observatio 113, n. 16); Menochius (1590, lib. 1, quaestio 52, n. 6); Tuschus (1661, VI, conclusio 267, Res iudicata quando pro veritate habeatur, vel non et quae sit ratio, n. 10).

73. Zasius (1550, lib. 42, tit.1 De re iudicata, lex 55 Iudex, nn. 13-14); Mynsinger (1601, decas 13, responsum 2, n. 126); Decianus (1579, vol. 1, cons.18, nn. 24 and 46); Menochius (1609, lib. 9, cons. 818, nn. 109-110); Gaill (1595, lib. I, observatio 144, nn. 6 in fine); Harpprecht (1657, tomus 4, lib. 4, tit. 17 De officio iudicis, § 7 Quod autem, nn. 21-22); Tuschus (1661, VI, conclusio 267, Res iudicata quando pro veritate habeatur, vel non et quae sit ratio, n. 55); Scaccia (1669, glossa 14, quaestio 2, n. 7 circa in medio); Voet (1731, tomus II., lib. XLIV, tit. 2 De exceptione rei judicatae, n. 1 in fine).

74. For the notion of res judicata in Roman law see Hanard (1995) and bibliography here quoted.

75. Mayali (1998, p. 2).

76. Menochius (1590, lib. 1, quaestio 52, n. 6).

77. Baldus de Ubaldis (1577, lib. 1, tit. 5 De statu hominum, lex 6 Libertini sunt qui).

78. Bertachinus (1570, II, entry: Veritas); Tuschus (1661, VIII, conclusio 166: Veritas attendenda est semper, n. 17). See also De Marsiliis (1574, § Secunda quaestio, n. 19) and Brunnemann (1704, cons. ultimum, n. 346). Brunnemann adds that veritas is also basis and foundation of justice.

79. Tuschus (1661, VIII, conclusio 166: Veritas attendenda est semper, nn. 8-12).

80. Tuschus (1661, VIII, conclusio 166: Veritas attendenda est semper, n. 43).

81. «Nam finis iudiciorum est investigatio veritatis» says Brunnemann (1747b, cap. I, De processu in genere, nn. 25-26).

82. Harpprecht (1657, tomus 4, lib. 4, tit.17 De officio iudicis, principium, n. 24): «Et quemadmodum Architecti seu Geometrae inaequalia spacia seu opera perpendiculo suo ad aequalitatem redigunt: ita judicem id, quod durius vel remissius est, exacto judicio ad aequalitatem perducere oportet». Johannes Friedrich Harpprecht belongs to a family of jurists and from 1592 to 1639, when he died, is professor at the University of Tübingen and eight times its Chancellor. He basically works on Justinian's Institutiones. With the title Opera omnia, his Commentaria in quatuor libros Institutionum Iuris Civilis is republished. His Tractatus criminalis, whose whole title is: Tractatus criminalis aliquot tituli libri 4 Institutionum, pertains to the titles of the Institutiones that deal with criminal law and is first published autonomously and then included in his commentaria. On Harpprecht see Schubart-Fikentscher (1971c).

83. Gaill (1595, lib. I, observatio 42, n. 9 in fine and n. 10) affirms: «Iudex enim est potissima pars, basis et fundamentum iudicii. Baldus ... iudicem ducem et imperatorem iudicii vocat. Et iudicatum dici non potest ab eo, qui ius dicendi potestatem non habuit». Andreas Gaill (1526-1587) belongs to an ancient noble family of Cologne, whose patrimony consents him to study not only at the university of Cologne, but also at some prestigious foreign universities like: Orléans and Bologna. Once back in Germany he works as a lawyer in his hometown, from 1558 to 1568 is member of the Reichskammergericht, in 1569 is member of the Reichshofrat in Vienna and in the last years of his life is Chancellor of the Prince-elector in Cologne. In 1578, he writes the Practicae observationes ... which is a systematic collection of the jurisprudence of the Reichskammergericht. He is basically a law practician and his works are mainly orientated towards practice, however the original structure of his Practicae observationes ... will be a model for future works in the jurisprudence collection. On Andreas Gaill see Otto (1995b); Kempis (1988); Sellert (1971).

84. Brunnemann (1754, lib. 7 , tit.48 Si a non competente iudice iudicatum esse dicatur, lex 2 Si militaris, n. 1). Scaccia (1669, glossa 7, quaestio 1, n. 10) refers the brocard in a partially different way. He affirms that «Iurisdictio est basis, et fundamentum totius processus, et sublato fundamento, caetera edificata corruunt».

85. Ius dicere and iurisdictio literally mean - the first in verb-form, the latter in noun-form - 'to say the law'. In other words the judge not only states the law finding the rule to be applied in statutes and customs but also creates it. He himself is a law source. Concerning the complex 
problem of the iurisdictio in the medieval and early modern period we suggest reading Costa (1969, pp. 144-153).

86. Zasius (1550, lib. 42, tit.1 De re iudicata, lex 4 Si se non obtulit, § 6 Condemnatum, n. 2); Gaill (1595, lib. I, observatio 42, n. 11);Carpzov (1739, pars 3, quaestio 107, n. 73); Scaccia (1669, glossa 7 , quaestio $1, n n .10-13)$. At $n .13$ Scaccia affirms that when the judgment is null and void because of lack of jurisdiction, the voidness cannot be rectified. He declares that the proceeding can be affected by three irremediable voidnesses due to the lack of jurisdictio, citatio and mandatum. Of the same opinion: Brunnemann (1747b, cap. I, De processu in genere, n. 27 circa in medio).

87. A written order coming from the prince or the emperor containing the delegation of jurisdiction on the judge's behalf.

88. Scaccia (1669, glossa 4, quaestio 4, nn. 37-45).

89. Decianus (1579, vol. 1, cons.18, nn. 1-2); Menochius (1609, lib. 1, cons.100, at nn. 7-10 examines the jurisdictio of the delegated judges, while at nn. 32-36 discusses the exception of voidness presented by Scipione's lawyers).

90. Zasius (1550, lib. 42, tit. 1 De re iudicata, lex 4 Si se non obtulit, $\S 6$ Condemnatum, n. 2 and lex 62 Cum quaerebatur, nn. 4-5); Tuschus (1661, VI, conclusio 267, Res iudicata quando pro veritate habeatur, vel non, et quae sit ratio, n. 37); Harpprecht (1657, tomus 4, lib. 4, tit.17 De officio iudicis, § 7 Quod autem, nn. 14-19); Brunnemann (1747b, cap. XXVII, De sententiae conceptione, nn. 44-54). The idea that the correct reconstruction of the truth can be reached only by way of a valid judicial proceeding can be envisaged in the quoted passages of these jurists. On judicial proceeding and truth see Resta (2004).

91. Decianus (1579, vol. 1, cons.18, nn. 38-51); Menochius (1609, lib. 1, cons.100, nn. 58-70). On defamation as start of the inquisitory trial see Bettoni (2006).

92. Decianus (1579, vol. 1, cons.18, nn. 194-196); Menochius (1609, lib. 1, cons.100, nn. 259-268).

93. Decianus (1579, vol. 1, cons.18, nn. 79-102); Menochius (1609, lib. 1, cons.100, nn. 167-172). On the point see also Scaccia (1669, glossa 4, quaestio 4, n. 4 and glossa 14 , quaestio 7, n. 44); Wesenbeck (1658, lib. 42, tit. 1 De re iudicata et de effectu sententiarum, n. 8)

94. Decianus (1579, vol. 1, cons.18, nn. 3-14); Menochius (1609, lib. 1, cons.100, nn. 36-42).

95. Carpzov (1739, pars 3, quaestio 107, n. 78). On the matter see also what I say in the $\S$ Res judicata and final judgment.

96. Harpprecht (1657, tomus 4, lib. 4, tit.17 De officio iudicis, principium, nn. 27-28).

97. Leyser (1744, cap. II, pp. 297-298). Augustin Leyser (1683-1752) is professor at the University of Wittenberg and judge at the local Schöppenstuhl. From 1713 to 1748 he edited his Meditationes ad Pandectas. He is interested in Roman law and in natural law and is an exponent of the Usus Modernus Pandectarum. On Leyser see Luig (1995). On interlocutory judgment see alsoZasius (1550, lib. 42, tit.1 De re iudicata, lex 55 Iudex, n. 3). The interlocutory judgment can be modified by the same judge who renders it. On the matter see Brunnemann (1747b, cap. XXVII, De sententiae conceptione, n. 4). Scaccia (1669, glossa 14, quaestiones 4 and 5) throughly explains the differences existing between final judgment and interlocutory judgment: in quaestio $17 \mathrm{nn}$. $10 \mathrm{ff}$. affirms that the interlocutory judgment can be modified, while the final judgment cannot because with the latter the judge has completed his duty (officium).

98. Zasius (1550, lib. 42, tit.1 De re iudicata, lex 31 Cum prolatis, n. 1-5). Zasius (1461-1535), a German jurist who has a humanist background, holds an interesting position on the matter. He, after stating the general rule which establishes that the judicial decision that is against the law is null and void, lists some exceptions. The judgment, for example is not null and void if it goes against a law which has fallen into disuse, or is obsolete, or dubious, neither is the judgment null and void if the judge explains the reasons why he judged against the law. Zasius refers a case judged by the Consistory of the Prince in Württemberg, in which the judges decided against a rule of law which was disused. Therefore, according to Zasius, the judge has also the added duty of verifying the 
effectiveness of the rule of law that he applies. On this point see also Brunnemann (1747b, cap. XXVII, De sententiae conceptione, n. 20); Harpprecht (1657, tomus I, tit.10 De nuptiis, § 11 Sunt et aliae personae, n. 109); Maranta (1568b, pars VI Et demum fertur sententia, Decisoria iudicii, tribus membris distinta: nempe sententia, appellatione et executione, actus I, nn. 117-118). Scaccia (1669, glossa 14, quaestio 1, n. 6) declares that the law judges the criminal, the judge cannot change the law, and has the duty to preserve it. The just judge judges according to the law and follows what is established by statutes and constitutions.

99. Clarus (1607, § finalis, quaestio 93, n. 2) refers what he sees practised in the Milan Senate (in its function as High Court). Its judges state the reasons for the decision only when the criminal defaults. At quaestio $85 \mathrm{n}$. 10 circa in medio the jurist affirms that the reasons for the decision must also be stated when the judge decides to reduce the punishment established for the crime in the ius commune or in the statutes. On the point see Daoyz (1742, pars II, ad verbum: sententia, nn. 49 and 58); Brunnemann (1747b, cap. XXVII, De sententiae conceptione, n. 20); Stryk (1841, lib. 42, tit.1 De re iudicata, § 10$)$.

100. Matthaeus (1644, lib. 48, tit. 17, cap. 2, n. 7). Concerning the question of the reasons for the decision, see Calamandrei (1979, pp. 206-207); Massetto (1989, pp. 1224-1245); Mancuso (1999, p. 218); Alessi (2001, pp. 83-86).

101. Zasius (1550, lib. 42, tit.1 De re iudicata, lex 31 Cum prolatis, nn. 3-4) affirms that the judgment against the communis opinio is not null and void if the judge can demonstrate that the law is on behalf of a different opinion, nor is the judgment against a judicial precedent null and void. The judgment is instead null and void if it is against a judicial precedent pronounced by the Prince. On the point see also Harpprecht (1657, tomus 4, lib. 4, tit.17 De officio iudicis, principium, nn. 32-39); Scaccia (1669, glossa 14, quaestio 8, nn. 38-41, quaestio 24, nn. 1-21, pp. 57-58). Scaccia affirms that the judgment against a communis opinio which is rightly founded is not null and void but unjust, and therefore appealable. The case is different if the judgment is pronounced against the communis opinio of the Sacro Regio Consiglio (High Court) of Naples. Indeed its decisions have the same legal strength of the law within the Kingdom, therefore any judgment which is against them is null and void.

102. Christynen (1661, vol. 4, decisio 95, n. 5); Groenewegen (1669, Institutiones, lib. 4, tit.1 De obligationibus quae ex delicto nascuntur, principium); Brunnemann (1752, tomus I, lib. 5, tit.1 De iudiciis et ubi quisque agere vel conveniri debeat, lex 15 Filiusfamilias, nn. 1-2, 6-10); Voet (1731, tomus I., lib. V, tit. 1 De judiciis et ubi quisque agere vel convenire debeat, n. 58). Guisius (1762, cap. IV, pp. 46-50) does not agree with the difficulties met by the judge in judging. On the matter: Schrage (1996) offers an insight in judge's liability in terms of civil law in France, Germany and England from medieval law to Twentieth-Century law; Durand (1996) is especially focused on France.

103. Harpprecht (1657, tomus 4, lib. 4, tit.17 De officio iudicis, principium, nn. 37-38).

104. Tudeschus (1588, tomus VII, lib. V, tit. De sententia excommunicationis, cap. 40 Per tuas, n. 12).

105. On the debate see Massetto (1989, pp. 1205-1207).

106. Gaill (1595, lib. I, observatio 42, n. 3 ) declares that the Reichskammergerichtin that it has a jurisdiction concurrent with that of the emperor, is not bound to the judicial evidence and can judge according to conscience. Decianus (1590, tomus I, lib. 2, cap. 14 Conscientiae veritas, n. 19) agrees and affirms that the potestas iudicandi according to conscience is a prerogative of the prince and of the Supreme Senate. Of the same opinion Scaccia (1669, glossa 14, quaestio 8, nn. 45, pp. 54-56).

107. Decianus (1590, tomus I, lib. 2, cap. 14 Conscientiae veritas, n. 24) thinks that the judge should judge according to judicial evidence, but, at the same time, he should not judge against his conscience: all that does not mean that he has to judge according to his conscience, but something different. He has to carry out a series of strategies that consent him to reach the truth (same chapter 14 nn. 15 ff.). Concerning this matter in Decianus, Pifferi (2006, pp. 336-352) states that the principle of judging according to judicial evidence is bent by Decianus to the advantage 
of the criminal law positivized by the prince and is conceived in such a way as to bind the judge to the law. Cassi (2004, pp. 148-152) adds that, according to Decianus, the good judge can follow his conscience if the witness whom he is questioning becomes pale or falters, therefore is not trustworthy and a conviction may not be based upon his words. On the debate concerning the role of the judge's conscience in his judging activity see also Harpprecht (1657, tomus 4, lib. 4, tit. 4 De actionibus, § 34 Si minus, nn. 2-23). A good synthesis of the debate can be found in Scaccia (1669, glossa 14, quaestio 8, nn. 1-56). Scaccia in order to support his thesis, which states the necessity that the judge judges according to the evidence gathered, affirms (in glossa 14, quaestio 8, n. 5 and in glossa 10, n. 25) that the judge cannot be judge and witness at the same time. For this reason the thesis, that consents the judge who has a direct knowledge of the truth to judge according to conscience, must be rejected.

108. Harpprecht (1657, tomus 4, lib. 4, tit.17 De officio iudicis, principium, n. 26); Scaccia (1669, glossa 14, quaestio 8, n. 17). Scaccia quotes Thomas de Vius (1897, vol. VII, pars IIa, IIae, quaestio 67, art.2, vers. Additur). On Thomas de Vius (Caietanus 1469-1534) see Pinchard, Ricci (1993).

109. Scaccia (1669, glossa 14 , quaestio 8, n. 38 ).

110. On the arbitrium iudicis see Meccarelli (1998).

111. On the role played by the poena extraordinaria in affirming a «new law of proof» see Langbein (1976, pp. 45-60). His theories generated a debate concerning the early affirmation of a new system of proof based on the intimate conviction of the judge. Many Italian law historians (Alessi, 1979, pp. 32-33 footnote 38; Marchetti, 1994, pp. 103-107; Rosoni, 1995, pp. 125-126; Meccarelli, 1998, pp. 250-254) have a different position on the matter, sustaining that the arbitrium iudicis used in this case to sentence the accused to a poena extraordinaria - is not outside the old system of legal proof but is part of it.

112. Scaccia (1669, glossa 14, quaestio 20, n. 1). Sigismondus Scaccia (1564-1634) is a lawyer in Rome and a judge at the Genoese Civil Rota. He published, in 1604, his Tractatus de iudiciis in which he examines some practical questions in order to help the work of the judge and, in 1619, his De commerciis et cambio. In 1628, he publishes his Tractatus de sententia et re iudicata which really corresponds to the third liber of his Tractatus de iudiciis. On Scaccia see Bergfeld (1995); Birocchi (2002, pp. 243, 250-251).

113. The following jurists state that the judgment is null and void: Zasius (1550, lib. 42, tit.1 De re iudicata, lex 33 Divus Hadrianus, nn. 4-9); Tuschus (1661, VI, conclusio 267, Res iudicata quando pro veritate habeatur, vel non, et quae sit ratio, n. 12); Harpprecht (1657, tomus 4, lib. 4, tit.17 De officio iudicis, principium, n. 40). The following jurists provide for review of judgment: Menochius (1590, lib. 1, quaestio 52, n. 5); Scaccia (1669, glossa 14, quaestio 32, n. 3); Carpzov (1739, pars 3, quaestio 139, nn. 38-39).

114. Mynsinger (1595, centuria II, observatio 25, n. 1 affirms that voidness and restitutio in integrum can be allowed by the same libel);Menochius (1609, lib. 9, consilium 818, nn. 111-117). Harpprecht (1657, tomus 4, lib. 4, tit. De exceptionibus, § 5 Item si in iudicio, nn. 15-22); Tuschus (1661, VII, conclusio 291 Restitutio in integrum datur contra rem iudicatam minori laeso, et maiori ex clausula, si qua mihi iusta causa, ex instrumentis de novo repertis, et quando secus, nn. 8-9); Scaccia (1669, glossa 14, quaestio 2, nn. 8, 45, questio 32, n. 3). According to the communis opinio the restitutio in integrum can be requested within four years from the final decision. See Scaccia (1669, glossa 14, quaestio 11, nn. 74-79). Zasius (1550, lib. 42, tit.1 De re iudicata, lex 33 Divus Hadrianus, nn. 4-9) does not agree and thinks that the decision made on the basis of false evidence can be rescinded ipso iure and for ever. Farinacius (1639, pars 3, quaestio 101, n. 112) holds a different position and states that against a manifestly unjust judgment appeal must be provided for even when it is forbidden. ${ }^{2}$

115. See Härter (2002); Griesebner (2002).

116. Maynus (1590a, lib. 3, tit. 1 De iudiciis, lex 12 [critical edition 14] Rem non novam, n. 1); Maranta (1568a, disputatio I An ordinarius loci ad mandatum delegati a principe tenetur exequi 
sententiam ipsius delegati evidenter iniustam, et an sibi de facto resistere, nn. 16-17; Menochius (1590, lib. 2, casus 339, n. 1); Tuschus (1661, VIII, conclusio 166: Veritas attendenda est semper, n. 40); Harpprecht (1657, tomus 4, lib. 4, tit.17 De officio iudicis, principium, n. 9). At n. 8 of the same passage, Harpprecht indicates the qualities which the judge must have with a very long series of adjectives. He has to be «gravis, sanctus, severus, incorruptus, inadulabilis, contra improbos, nocentesque, immisericors, atque inexorabilis, erectusque et arduus, ac potens, vi et maiestate aequitatis veritatesque terrificus ... pius, bonus, iustus, aequus, fortis, patiens, benignus, prudens, constans, verax, candidus, sobrius, liberalis, diligens, secretus, facilis, iuris publici ac privati, nec non morum, hominum et Reipublicae peritus». We find the same list of qualities which every judge must have in Scaccia (1669, glossa 4, quaestio 2, n. 60). The jurist at quaestiones 1 and 2 indicates the criteria to be followed when choosing a judge.

117. Calamandrei (1979, p. 156). Garnot (2004) deals with a problematic issue connected with the judicial error: the relationship between judicial evidence and the intime conviction of the judge.

118. Bertachinus (1570, II, entry: Error iuris and Error facti); Farinacius (1639, pars 3, quaestio 111, n. 481).

119. Zasius (1550, lib. 42, tit.1 De re iudicata, lex 27 Praeses provinciae, nn. 2-4);Harpprecht (1657, tomo I, tit.10 De nuptiis, § 11 Sunt et aliae personae, n. 109); Carpzov (1739, pars 3, quaestio 139, n. 39). On the point see Calamandrei (1979, p. 167); Padoa Schioppa (1970, pp. 26-27).

120. Zasius (1550, lib. 42, tit.1 De re iudicata, lex 62 Cum quaerebatur, nn. 10-11); Wesenbeck (1658, lib. 42, tit. 1 De re iudicata et de effectu sententiarum, n. 10); Gaill (1595, lib. I, observatio 127, n. 8);Scaccia (1669, glossa 14, quaestio 32, n. 55); Brunnemann (1747b, cap. XXVII, De sententiae conceptione, nn. 67 in fine and 68, cap XXVIII De appellationibus, n. 108). Brunnemann at n. 109 of caputDe appellationibus refers to a practice that spread throughout Germany after the new Imperial Constitutions were enacted. According to them the quaerela nullitatis should be presented in the same ten days that are given to make an appeal. The only exceptions to the rule are represented by the irremediable voidnesses related to the person of the judge, of the parties or to essential acts of the proceeding. Certain jurists affirm that the judgment does not pass inrem judicatam when it is null and void:Maranta (1568b, pars VI Et demum fertur sententia, Decisoria iudicii, tribus membris distinta: nempe sententia, appellatione et executione, actus I, n. 153); Farinacius (1589, liber I, quaestio 25, n. 5); Scaccia (1669, glossa 14, quaestio 2, nn. 38-39); Savelli (1748, tomus 4 , § Sententia, n. 30). Brunnemann (1747b, cap. XXVII, De sententiae conceptione, n. 67) affirms that the final judgment does not pass inrem judicatam only if the res judicata is notoriously null and void. Other jurists affirm that during the appeal presented by the party, questions relating to the unjustice of the decision can be treated together with questions related to its voidness, because they should not be excluded from the appeal case. Once appeal is presented it is not necessary to present the quaerela nullitatis as well. However if the party failed to appear or to pursue for a two year period, he not only loses the case on appeal, but also the case for voidness. See: Zasius (1550, lib. 42, tit.1 De re iudicata, lex 62 Cum quaerebatur, nn. 7-9);Mynsinger (1601, decas 7, responsum 68, n. 15). Of a different opinion:Gaill (1595, lib. I, observatio 135, nn. 6-8); Brunnemann (1747b, cap. XXVIII, De appellationibus, n. 109 circa in medio).

121. Scaccia (1669, glossa 14, quaestio 2 , nn. 8, 40). On the matter see Calamandrei (1979, pp. 149-155); Padoa Schioppa (1970, pp. 43-52).

122. Maranta (1568b, pars VI Et demum fertur sententia, Decisoria iudicii, tribus membris distinta: nempe sententia, appellatione et executione, actus I, n. 155).

123. Zasius (1550, lib. 42, tit.1 De re iudicata, lex 62 Cum quaerebatur, n. 9); Wesenbeck (1658, lib. 42, tit. 1 De re iudicata et de effectu sententiarum, n. 10); Maranta (1568a, disputatio I An ordinarius loci ad mandatum delegati a principe tenetur exequi sententiam ipsius delegati evidenter iniustam, et an sibi de facto resistere, nn. 15-17);Clarus (1607, § finalis, quaestio 94, n. 10); De Marsiliis (1574, § Opportune, n. 6 circa in medio, n. 10);Menochius (1609, lib. 9, cons. 818, nn. 110); Tuschus (1661, III, conclusio 489, Executio sententiae non retardatur multis casibus, n. 22);Farinacius (1639, pars 3, quaestio 101, n. 111 
circa in medio);Brunnemann (1747b, cap. XXVIII, De appellationibus, nn. 110-111); Scaccia (1669, glossa 14 , quaestio $10, \mathrm{n} .30$, quaestio $11, \mathrm{nn} .54-69$ and quaestio $20 \mathrm{nn} .8-13$ ). In the latter quaestio Scaccia affirms that also the unjust res judicata should not be executed even in the case where the party did not appeal against it. He says that the unjust judgment does not pass in rem judicatam. He refers the practice in the Papal States and relates that this is also what usually happens in the courts of the Grand Duchy of Tuscany.

124. Gaill A., (1595, lib. I, observatio 127, nn. 9-10).

125. On the matter see Cordero (1985, p. 622).

126. Brunnemann (1752, tomus I, lib. 3 , tit.2 De his qui notantur infamia, lex 22 Ictus fustium, nn. 2-6): «Non tamen possum mihi persuadere, quod regulae illae de firmitate rei iudicatae, eo usque possint extendi, ut etiam res iudicata noceat corpori ac famae, quae vitae aequiparatur innocentis. Nec lex hanc potestatem dedit judici, ut innocentem infamem facere possit».

\section{ABSTRACTS}

In this article the author investigates the errors that can make the judgment null and void and, therefore, produce the reversal of the res judicata.

She - starting from the definition of res judicata as the irrevocable end of a correctly constructed judicial proceeding - tries to find out what, in the Sixteenth and Seventeenth centuries, gives substance to it in order to better understand the discipline of the miscarriage of justice of the time. She will, therefore, see the differences between final judgment and res judicata; the relationship between appeal and res judicata; the elements which constitute the authority of the res judicata; the iuris et de iure presumption: res iudicata pro veritate habetur which gives it foundation; and the judicial errors made in a criminal judgment that are taken into consideration by the Italian and German ius commune jurists.

Dans cet article l'auteure étudie les erreurs qui peuvent rendre le jugement nul, et en conséquence, produire la rescision de la chose jugée.

À partir de la définition de la chose jugée comme la fin irrévocable d'un procès criminel correctement construit, elle tente de découvrir ce qui, aux $\mathrm{XVI}^{\mathrm{e}}$ et $\mathrm{XVII}{ }^{\mathrm{e}}$ siècles, lui donne substance afin de mieux comprendre la discipline de l'erreur judiciaire du temps. Elle verra, donc, les différences entre le jugement final et la chose jugée; le rapport entre l'appel et la chose jugée; les éléments qui constituent l'autorité de la chose jugée; la présomption iuris et de iure: res iudicata pro veritate habetur qui constitue sa base; et les erreurs judiciaires commises dans un jugement criminel qui sont prises en compte par les juristes italiens et allemands de ius commune.

\section{AUTHOR}

\section{ANTONELLA BETTONI}

Università degli studi di Macerata, Istituto di Studi storici, via G. Garibaldi, 20, 62100 Macerata, bettonel@unimc.it

Antonella Bettoni completed a doctoral thesis in History of Law in 2004 entitled «Habeas bonum nomen». Dottrine dell'infamia nell'esperienza di diritto comune (secoli XVI-XVII) («Have a good name». 
Doctrines of infamy in the ius commune experience (16th-17th centuries). Her present research interests include early modern and modern juridical doctrine of infamy, of 'social danger', and of certain aspects of the criminal trial (crime information, res judicata). She published the following articles: Bettoni, A., Il caso Castritius. Giurisdizione urbana e privilegi accademici nella Germania del XVII secolo, Annali della Facoltà di Giurisprudenza - Università degli studi di Macerata, nuova serie (2000-2002, V, pp. 93-138); Bettoni, A., The perception of 'social danger' among ius commune jurists. A reconstruction of the concept of malus in Sixteenth and Seventeenth century Italian and German juridical doctrine, Liverpool Law Review (2005, XXVI, 1, pp. 45-73); Bettoni, A., Voci malevole. Fama, notizia del crimine e azione del giudice nel processo criminale (secc. XVI- XVII), Quaderni Storici (2006, XLI, 1, pp. 13-38). She is currently a research assistant at the Istituto di Studi Storici, University of Macerata, Italy. 